IZA DP No. 10239

Gender Quotas: Challenging the Boards, Performance, and the Stock Market

Giulia Ferrari

Valeria Ferraro

Paola Profeta

Chiara Pronzato

September 2016 


\title{
Gender Quotas: Challenging the Boards, Performance, and the Stock Market
}

\author{
Giulia Ferrari \\ INED \\ Valeria Ferraro \\ Boston College \\ Paola Profeta \\ Bocconi University and DONDENA \\ Chiara Pronzato \\ University of Turin and IZA \\ Discussion Paper No. 10239 \\ September 2016 \\ IZA
P.O. Box 7240
53072 Bonn
Germany \\ Phone: +49-228-3894-0 \\ Fax: +49-228-3894-180 \\ E-mail: iza@iza.org
}

Any opinions expressed here are those of the author(s) and not those of IZA. Research published in this series may include views on policy, but the institute itself takes no institutional policy positions. The IZA research network is committed to the IZA Guiding Principles of Research Integrity.

The Institute for the Study of Labor (IZA) in Bonn is a local and virtual international research center and a place of communication between science, politics and business. IZA is an independent nonprofit organization supported by Deutsche Post Foundation. The center is associated with the University of Bonn and offers a stimulating research environment through its international network, workshops and conferences, data service, project support, research visits and doctoral program. IZA engages in (i) original and internationally competitive research in all fields of labor economics, (ii) development of policy concepts, and (iii) dissemination of research results and concepts to the interested public.

IZA Discussion Papers often represent preliminary work and are circulated to encourage discussion. Citation of such a paper should account for its provisional character. A revised version may be available directly from the author. 


\section{ABSTRACT \\ Gender Quotas: Challenging the Boards, Performance, and the Stock Market ${ }^{\star}$}

In 2011, Italy introduced gender quotas for boards of directors of companies listed on its stock market. Comparing before and after the reform within firms, we find that quotas are associated with a higher share of female board directors, higher levels of education of board members, and a lower share of older members. We then use the reform period as an instrument for the share of female directors and find no significant impact on firms' performance. Interestingly, we find that the share of female directors is associated with a lower variability of stock market prices. We also run event studies on the stock price reaction to the introduction of gender quotas. A positive effect of the quota law on stock market returns emerges at the date of the board's election. Our results are consistent with gender quotas giving rise to a beneficial restructuring of the board, which is positively received by the market.

JEL Classification: J20, J48, J78

Keywords: education, age, financial markets

Corresponding author:

Paola Profeta

Bocconi University

Via Roentgen 1

20136 Milan

Italy

E-mail: paola.profeta@unibocconi.it

\footnotetext{
* We thank Luca Bagnato, Vittoria Dicandia and Paolo Longo for excellent research assistance. We thank the Department of Equal Opportunities of the Italian Presidency of Council of Ministries for the partnership in the project "Women mean business and economic growth" financed by the European Commission, DG Justice, which provided financial support for a part of the data collection. We thank J. Ignacio Conde-Ruiz for data on the Spanish companies. We thank Mario Amore, Massimo Anelli, Marianne Bertrand, Paolo Colla, Luca Flabbi, Vincenzo Galasso, and Fabiano Schivardi for very useful comments. We thank participants at seminars at NOVA School of Business and Economics and Collegio Carlo Alberto. All errors are ours.
} 


\section{Introduction}

Women are underrepresented among top leadership positions. The glass ceiling the maximum professional level a woman can achieve before a strong preference for males occupying these positions emerges - is still a dominant phenomenon. Even in countries in which women participate more in the labour market, only a minority makes it to the highest positions. According to the World Economic Forum (2015), only $59 \%$ of the gender gap in economic opportunities has been closed around the world. As the economic gender gap has been reduced by only $3 \%$ in the past 10 years, the World Economic Forum claims that it will take another 118 years to vanish completely.

There is an urgent need to accelerate the movement towards gender equality. In fact, not only is equality between men and women in itself an important development goal, but women's economic participation is also "a part of the growth and stability equation" (IMF, 2014). As women represent half of the population, and have talent, human capital and productivity equal to men, the global economy would benefit from boosting women's participation in the labor force. The absence of women from positions of leadership is at odds with the strategy of exploiting talent to promote business and performance (IMF, 2014). This is particularly relevant in times of modest economic growth. A greater involvement of women in the economy may also have beneficial effects on cultural development. Dominant gender stereotypes and social norms have played a crucial role in generating gender gaps. Learning from other women's experience in the labor market may generate a virtuous and persistent circle of gender equality through changes to the cultural process (Fernàndez, 2013; Fernàndez et al., 2004).

Gender quotas have been proposed to accelerate the process towards economic gender equality and to promote women's empowerment. ${ }^{1}$ Norway pioneered the introduction of gender quotas for boards of directors in 2005. Italy, France, and Germany, among others, followed. Three European Directives on gender quotas have been proposed and are currently under consideration, while the debate is open in many other countries. However, gender quotas are controversial. They have been widely advocated for achieving a gender-balanced representa-

\footnotetext{
${ }^{1}$ In parallel, gender quotas have been introduced to reduce political gender gaps, the other crucial dimension of gender inequalities (see Section 2 for more references).
} 
tion in the top of economic positions, a fundamental element of economic gender equality around the world (see OECD, 2012). Yet, opponents of quotas argue that they violate meritocracy, with costly consequences: by equalizing outcomes rather than opportunities, quotas risk promoting less-qualified individuals, who are likely to perform poorly (Holzer an Neumark, 2000). For instance, if highly qualified women cannot be found, board gender quotas may produce negative effects on the performance of companies and negative stock market reactions (Ahern and Dittmar, 2012). Are these negative consequences the unavoidable cost of achieving more gender-balanced representation?

What we know so far about the effects of board gender quotas on the economy is based on the Norwegian experience. In late 2003, a law was approved in Norway mandating $40 \%$ representation of each gender on the board of companies listed on its stock market. The Norwegian law imposed a dramatic and rapid transformation of the composition of boards of directors. Research has shown that the Norwegian law has been effective at increasing the number of women on boards up to the $40 \%$ threshold, but it has not been able to reduce gender gaps overall (Bertrand et al., 2014). Moreover, an influential study by Ahern and Dittmar (2012) shows that the increase in women on boards in Norway imposed a significant cost on firms and the stock market. ${ }^{2}$

This paper provides new evidence based on the introduction in July 2011 of board gender quotas in Italian listed companies. The so-called "Golfo-Mosca" (the names of the two authors) law mandates gender-balanced representation of either gender on the board of directors and statutory auditors of publicly listed companies. Unlike in Norway, the Italian quotas are temporary and gradual. In fact, the measure will be in place only for three consecutive board elections. The required target of representation of either gender is set at $1 / 5$ for the first election after August 2012, to be increased to 1/3 for the following two board elections. Different from Norway, Italy features a very conservative gender culture, and ranks poorly in Europe in almost all gender statistics (see Profeta et al., 2014): in the last ten years, women's participation in the labour force has remained stable, around only $47 \%$, the lowest value in Europe, if we exclude Malta. In this context, the quota policy was perceived as the only possible way to start the process towards gender equality. But what about its costs? A country with

\footnotetext{
${ }^{2}$ See, however, results in Nygaard (2011) and the references detailed in Section 2.
} 
no economic growth certainly cannot afford substantial economic costs. In this paper, we find no evidence of significant costs, neither on companies nor for the stock market, associated with the introduction of board gender quotas in Italy. On the contrary, we find beneficial effects of the quota policy.

To perform our analysis we manually collected individual data on all members of the boards of Italian listed companies in the period 2007-2014 (4,627 different individuals), as well as firm-level data on relevant outcomes of these companies (243 companies) and stock-market prices. With these data, we are able to address four questions that are fundamental for evaluating the efficacy of quotas in the process of promoting women's empowerment vis-à-vis the costs they may generate: Do the composition of the boards and the characteristics of the members change after the introduction of quotas? Do firms' outcomes, such as economic performance and variability of stock market prices, change after the introduction of gender quotas? How does the stock market react to the announcement of board gender quotas? How does the stock market react to the introduction of board gender quotas at the boards' elections?

Our results can be summarized as follows. First, to understand the effects of board gender quotas on the selection process, we compare before- and after reform changes in board member characteristics, such as gender, age, and education, for each firm, while controlling for time trends. We find that, when gender quotas are enforced, firms show a higher share of women directors (well above the required threshold), higher average education levels of all members of the board, and lower ages than before the quotas. Gender quotas trigger a process of better selection of the entire board. We do not find an increase in board members belonging to the same family, nor a clear increase in the average number of positions held by each board member.

Second, to assess the causal effect of women's empowerment on firms' performance, we use the reform period, which is exogenous to firms' decisions, as an instrument for the share of female directors. Although the short time period (two years) after the introduction of gender quotas does not allow us to assess the long-term effects, our analysis shows that so far quotas in Italy have not been associated with different (for instance, worse, as in Norway) firm performance. However, consistent with the existing evidence that women are more risk-averse than men (see a review in Bertrand, 2011), we show that women's empowerment 
reduces the variability of companies' stock prices - a dimension not addressed in the Norwegian context.

Third, since we are considering listed companies, we measure the consequences of the introduction of gender quotas on the stock market. Our event study at the date of the announcement of the law compares Italian companies with Spanish companies listed on the Madrid Stock Exchange. While we do not identify significant effects at the day of the approval of the law by the Senate, we do find a negative effect for Italian companies at the day of the approval of the law. However, since this effect had no differential impact on stock price performance of Italian companies that would be first affected by the reform relative to other companies, it is difficult to link it to the quota law.

Fourth, to provide a final assessment of the impact of gender quotas on the stock market, we perform an event study at the day of board elections. We find that the introduction of gender quotas in Italy is associated with better firm returns: companies with a smaller share of women in the pre-reform board composition (i.e., farther from the quota target) experience better stock market results at the date of the first board election after the approval of the law, with respect to companies that were already closer to the target. In other words, the renewal of the board associated with gender quotas, which is clear at the day of the election, and may still be uncertain at the day of the announcement of the law, has positive effects on the stock market. This result is different from what was found by Ahern and Dittmar (2012) in the Norwegian case.

Overall our results support the idea of a potential double dividend from gender quotas. Not only might gender quotas contribute to women's empowerment, they may also encourage a better selection mechanism, mainly by increasing the level of education of the entire board. As long as promoting education goes hand-in-hand with exploiting talents, a fact that is particularly relevant in our economies and that represents a crucial engine for business (see OECD, 2012), our results point out the beneficial effects of quotas. More competition emerges with the entry of qualified women. In countries such as Italy, dominated by a male gerontocracy, where boards of directors were not necessarily populated by the most competent and most qualified people for the job, as documented by Bianco et al. (2015), the introduction of gender quotas induces a beneficial restructuring of the boards, which is positively received by the market. 
The paper is organized as follows: the next section reviews the related literature and Section 3 describes the Italian law. Section 4 presents the data that we will use throughout the different analyses performed in the paper. The four sections that follow present analysis and results related to our four fundamental questions: the impact of the law on the characteristics of the boards, the impact of the law on firms' performance and the variability of stock prices, the impact of the announcement of the law on stock market prices, and the effect of the election of the board under the new rule on stock market prices. Each of these sections presents first the empirical methodology adopted and then the results. Conclusions are in Section 9. Additional evidence is provided in the appendix.

\section{Related literature}

The literature on the effects of gender quotas in the context of business and/or politics, is vast (see Profeta et al., 2014, Pande and Ford, 2011 for reviews). Gender quotas are a controversial policy. The main argument in favor of the adoption of gender quotas is their effectiveness as a means to equalize opportunity in specific areas where women face systematic barriers due to discrimination or persistent stereotypes (Holzer and Neumark, 2000). These policies may lead to a redistribution of jobs, positions, contracts, or parliament seats in favour of women, and thus allow for a fair distribution of rewards of good jobs. Moreover, if women who benefit from affirmative action are largely qualified to successfully perform the tasks they are appointed to, the benefits do not remain within the group of women but spread to the entire economy. If women accumulate more human capital that raises their productivity, these policies may even increase efficiency (Conde Ruiz et al., 2015). Quotas are an instrument (often considered the only one) to break down the masculine monopolistic power, which obviously does not lead to an equal outcome, but probably neither to an efficient one. Critics of affirmative action instead share the view that the underrepresentation of women is not due to discrimination, but is merely the result of women's choices, especially related to fertility and motherhood. Thus, by equalizing outcomes rather than opportunities, affirmative action policies risk promoting less-qualified

individuals, who very likely will perform poorly. Not only is there a risk of decreasing the average quality if there are not enough women with the appropriate 
qualifications to be appointed, but a "mismatch" may occur if women are allocated to positions in which they are unable to perform successfully. Recent studies have also doubted the effectiveness of quotas in reducing gender inequalities. ${ }^{3}$ Bertrand et al. (2014) have found that gender quotas for listed companies in Norway have improved the representation of female employees at the very top of the earnings distribution within affected firms, while they had no trickle-down effects and no other significant effects on reducing gender gaps. ${ }^{4}$

In the context of business, the study of the effects of board gender quotas is particularly meaningful for identifying the causal effects of women's representation on economic outcomes and to overcome the typical endogeneity concerns that are involved in addressing this relationship. A well-studied example is Norway. Several studies assess whether the increased female representation in top positions due to the quota had any impact on firms' economic performance. The evidence is not conclusive. Matsa and Miller (2013) find that firms affected by the quota law have fired fewer workers, increasing relative labor costs and employment levels and reducing short-term profits. Ahern and Dittmar (2012) show that gender quotas caused negative market reactions, because young and lessexpert members are serving on boards. However, Nygaard (2011) shows that this effect depends on asymmetric information between independent members of the boards and the companies' managers (see also Ferreira, 2015). Board gender quotas in Italy provide new evidence on the causal effects of women's empowerment in the corporate sector on economic outcomes. Our study will contribute to understanding whether negative economic outcomes are a necessary cost to be paid for achieving more gender-balanced representation.

In the context of politics, ${ }^{5}$ recent studies have shown that gender quotas are not at odds with meritocracy: gender quotas help increase the quality of repre-

\footnotetext{
${ }^{3}$ The effectiveness of gender quotas in breaking the glass ceiling has been questioned by, among others, Bagues and Esteve-Volart (2010), who focus on the impact of quotas in selection procedures.

${ }^{4}$ However, Wang and Kelan (2013) find that the Norwegian gender quota law and the subsequent higher presence of female directors increase the likelihood of women being appointed to top leadership roles.

${ }^{5}$ In the context of politics, the Indian reservation system has been exploited as a very useful case of analysis providing evidence on the impact of quotas not only on the number of female representatives (Beaman et al., 2009; Pande and Ford, 2011), but also on the policies implemented (Chattopadhyay and Duflo, 2004).
} 
sentatives. In the Italian political context, gender quotas have been associated with better-quality politicians (Baltrunaite et al., 2014), measured by their level of education. In the Swedish case, the 'zipper' quota requiring an alternating between a male and a female candidate on the party's list of candidates has increased both female representation and, interestingly, the competence of male politicians (Besley et al., 2013). This paper will contribute to understanding to what extent this result also applies to the business context.

A sizeable literature has analyzed the relationship between female leadership and firms' outcomes outside the context of gender quotas. Research has developed in the field of economics, finance, and management. Results are not fully conclusive. Having both men and women in top positions of a company may have positive consequences on performance. In a heterogeneous context, the perspectives are enlarged, the pool of talent and qualification are diversified, and the shareholders are better represented (see, among the others, Van der Walt and Ingley, 2003; Rose, 2007, Hoogendoorn et al., 2013). The female style of leadership, including higher levels of risk aversion (see Bertrand, 2011 for a survey), may also produce performance benefits. These results are, however, challenged by recent studies. Adams and Ferreira (2009) find a negative impact of gender diversity on performance measures such as return on assets (ROA) and Tobin's Q, while Gagliarducci and Paserman (2014) find no evidence that female leadership is related to performance outcomes. The view itself that women are more risk-averse than men is challenged by Adams and Ragunathan (2013) and Adams and Funk (2012). Other studies qualify the conditions under which a positive relationship between women's empowerment and firms' performance may emerge: the existence of a critical mass of women (Schwartz-Ziv, 2015), a positive interaction among female CEOs and women on boards (Amore et al., 2014) or among female CEOs and female workers employed at the firm (Flabbi et al., 2014).

Non-conclusive results also emerge when looking at the relationship between women's empowerment and stock market returns. Wolfers (2010) finds no differences in stock price performance between female-headed firms and other firms. Dobbin and Jung (2011) argue that women on corporate boards are more likely to adversely affect stock prices, and less likely to positively affect profitability. Ryan and Haslam (2005) find a significant increase in share price following the appointment of a female director. However, women are more likely to be ap- 
pointed in times of general financial downturn in the stock market, and thus have a more precarious position (the so-called "glass cliff"). How the stock market reacts at the appointment of a female director is not unambiguous: Chapple and Humphrey (2011) for Australia find no reaction, Adams et al. (2012) find a positive reaction, and Lee and James (2007) find a negative reaction. ${ }^{6}$ Adams and Ferreira (2003) find that firms facing more variability in their stock returns have fewer women on their boards.

Finally, our paper also speaks to the corporate governance literature, which has underlined the importance of diversity for boards' quality and their functioning (see Dhir, 2015). Our results suggest that quotas may be effective at increasing diversity and encouraging a better selection of board members. This is particularly important for the Italian case (see Consob, 2015), where the prequota situation was characterized by the presence of women almost exclusively being appointed on boards of family firms, and by a selection process not purely meritocratic (Bianco et al., 2015).

\section{The Italian law}

Women are largely underrepresented in the Italian labor market: in the last ten years the labor force participation rate of Italian women has been stable, around only 47\%, against an European average of 60\%. In 2009 the average share of women on the boards of directors of publicly listed companies was $7 \%$, one of the lowest in Europe. Despite this context - not very favorable to women's representation - Italy introduced board gender quotas in July 2011 (Law 120/2011). The law was first proposed in May 2009 by a member of the Chamber of Deputies, Lella Golfo, of the centre-right coalition; in November 2009, the draft was resubmitted by another member of the Chamber of Deputies, Alessia Mosca, of the centre-left coalition. However, it was only two years later that the draft began being discussed thoroughly by the Italian Parliament. In February 2011 two important amendments to the original draft were introduced: the gradual implementation of the law and the sanction system in case of non-observance.

\footnotetext{
${ }^{6}$ For Italy see also Rossi and Cebula (2015), who, for a small sample of 100 Italian listed companies during the period 2012-2014, find a positive reaction within 20 days around the date of the announcement of the composition of the board.
} 
On March 9, 2011, the draft was approved by the Parliamentary Commission in charge of the quota law, and on March 15, 2011, the draft was approved by the Senate. The final draft of the law was approved by the Italian Parliament on June 28, 2011, by an overwhelming majority.

Law 120/2011, also known as the "Golfo-Mosca" law, mandates that publicly listed companies should have at least $1 / 3$ of either gender on their boards of directors and statutory auditors. ${ }^{7}$ Boards of companies listed on the Italian stock exchange are elected every three years. The quota is implemented gradually: at the first board election, the required target is $1 / 5$ and becomes $1 / 3$ for the following two elections. The measure is temporary and remains in place for three consecutive board elections only. If a firm does not comply, CONSOB (the regulatory body of the Italian stock exchange) warns the company, which has four months to comply. The warning system continues with a fine ranging from a minimum of EUR 100,000 to a maximum EUR 1,000,000. Should the company persist in failing to comply without responding to the second warning within the following three months, the law states that the appointment of every elected member will be invalidated. The law was approved on July 12, 2011, applicable to listed companies, but its effects became binding for firms one year after approval, specifically on August 12, 2012. We refer to the interval period between July 12, 2011, and July 12, 2012, as the "phase-in" period. On February 2012, the law was extended to state-owned companies, i.e. public companies under the control of the government, with immediate effect. ${ }^{8}$ The crucial features of the law are as

\footnotetext{
${ }^{7}$ Italian companies may choose among the following governance models: a one-tier governance system (Monistico); a dual-tier system with distinct supervisory (Consiglio di sorveglianza) and management (Consiglio di gestione) functions; or the traditional model with a decision-making board (Consiglio di amministrazione or amministratore unico) and a separate board of statutory auditors (Collegio sindacale) with monitoring and control functions. In this last model, which is the one used by the majority of companies $(96.2 \%$ of the companies listed on the main market in 2013 and $94.8 \%$ in 2012), members of both boards are elected by the shareholders. The board of directors includes executive directors, non-executive directors, and independent directors, while the board of statutory auditors is composed of three to five experts, who must be independent. The size of the board varies according to company size and sector, with financial companies having larger boards than non-financial ones. On average, the board of directors is made up of 10 directors. For more details on how companies are regulated and the activities of the boards, see Profeta et al. (2014).

${ }^{8}$ While publicly listed companies are, according to CONSOB, around 240 , we estimate around 4,000 state-owned companies that must comply with the gender quota law. For them, the Department of Equal Opportunities at the Presidency of Council of Ministries is in charge of the monitoring and sanctioning system. Detailed information on these companies, however,
} 
follows: time-limited nature, gradualism, sanctions, and the interaction between private and public. These features make the Italian law different from Norway's. In particular, the time-limited nature is a specific feature of the Italian design of the reform. It is consistent with the idea that gender quotas are described as a measure to shock and thus break up the male-dominated power, and to lead the market to a new, more gender-balanced, equilibrium. The idea behind this feature is that when the new equilibrium is reached, the quotas will no longer be necessary. Gradualism is also a different feature from the Norwegian policy. It recognizes the fact that, especially in conservative countries such as Italy, firms need time to adapt to changes. Gradualism may help to turn changes, which can be costly, into opportunities.

As the law on gender quotas was approved in August 2011 and implemented the year after (August 2012), and as the boards are elected every three years, we can classify boards in three, almost equally distributed, groups: 1) those changing their composition in 2011 before August, which we call "pre-reform"; 2) those appointing new members in the transition period (i.e., between August 2011 and July 2012), called "phase-in"; and 3) those renewing in the new regime after August 2012, called "post-reform". ${ }^{9}$ Companies are exogenously assigned to the three groups: the date of renewal of the board depends on the past, instances occurred well before the initial discussion on the gender quotas law, which cannot be manipulated according to the timing of the law. In any case, we check that no firm moved forward its board election to postpone the introduction of the quota. We will use this division into groups in several parts of the following analysis.

Figure 1 clarifies the timeline of the implementation of the law.

\section{The Data}

We focus on listed companies and collect several categories of data: (i) individual data, containing the main socio-demographic information on the members, male and female, of boards of directors and boards of statutory auditors of the companies listed on the Italian stock exchange from 2007 to 2014; (ii) firm-level data,

is not available. Thus, our analysis concentrates on listed companies.

${ }^{9}$ Since elections are typically held between April and June, post-reform firms have board elections in 2013 and 2014. 
including a set of financial and economic information on each company listed on the Italian stock exchange, such as number of employees, production, profits, firm value, returns on assets, returns on equity, debts and assets; (iii) stock market data, such as the daily stock price and the daily closing price of the FTSE MIB.

The list of companies to which the law applies is found at the CONSOB website. We compare this list with the one in Aida, the Italian branch of Amadeus (Bureau van Dijk), the database of comparable financial and business information on Europe's 500,000 largest public and private companies by assets. From 2011 to 2014, the list of Italian publicly listed firms included roughly 245 firms each year.

For each firm, we collected the election date of the board of directors by accessing the Corporate Governance section (Relazione di Corporate Governance or Relazione sul governo societario e gli assetti proprietari) of the company's website. When this was not available, we searched on the website of the Milan Stock Exchange (Borsa Italiana), in the section where official corporate documents were collected. If the Corporate Governance information was in the stock exchange records, the election date was collected from the convocation notice of the shareholder meeting for the board election in the official journal of record. Elections were held between April and June. For each firm we collected the full names of the board members as of June 30 for every year from 2007 to 2014. The information on board members was collected from CONSOB - the regulatory body of the Italian stock exchange, where the names and roles of board members are available for each company beginning in the 1990s. Most of the time, the gender of each member was unambiguously identified through the person's first name; when the first name was ambiguous, we searched for a photo of the person.

\subsection{Individual data}

Information on the individual characteristics of board members is not available in an organized manner, and it is sparse among the documents that each company must provide to CONSOB when a board member is elected. We therefore manually collected the CVs of all members of the boards of directors and boards of statutory auditors of listed companies elected between 2007 and 2014 . 
From our inspection of the 4,627 CVs of these different individuals, we collected individual data for each member of the board on the following characteristics: $^{10}$ name and surname, age, gender, state of birth and residence, type of board (board of directors, board of statutory auditors, management board, supervisory board), position on the board (president, vice-president, CEO, administrator/advisor, auditor), qualification (diploma or lower degree, bachelor's degree, graduate degree), university where the degree was obtained (distinguishing in particular whether the university was in Italy or abroad), field of education (if graduated); any kinship with other members of the board. From this information we constructed the following variables:

1) Women's empowerment, which is captured by the share of women on boards and whether this share exceeds the first target of the law, i.e. 20\%. We also looked at the role of members of the board by gender, distinguishing between presidents and CEOs.

2) Education, which is measured by the level of education of each board member (university degree or graduate education) ${ }^{11}$ and a variable that indicates whether the individual has studied abroad or not. We also consider fields of study (economics, law, engineering, political science, and others). To capture the level of field heterogeneity in each board, we built a Herfindahl index. ${ }^{12}$

3) Age, which is captured by the percentage of board members older than 60 or 70 years.

4) Family relationships, which is captured by the percentage of board members who belong to the company's owner family.

5) Multiple positions, i.e. the average number of board positions held by each member. ${ }^{13}$

\footnotetext{
${ }^{10}$ Despite the effort exerted to have a complete dataset, for a limited number of boards we were not able to obtain information on all members. However, we checked that our results did not substantially change when excluding companies with more than $10 \%$ of missing values on the education variable, which was the most critical to obtain.

${ }^{11}$ We consider the percentage of members with at least a university degree and the share of board members holding a graduate degree. The first variable represents the proportion of board members who hold a university degree of any kind, namely bachelor's degree, Master of Arts and Master of Science, MBA, or PhD. The second variable is the proportion of members with a $\mathrm{PhD}$, a Master program, or MBA.

${ }^{12}$ This index is widely used as a measure of diversity, under the expectation that higher heterogeneity is related to better performance, see Adams et al. (2012).

${ }^{13} \mathrm{~A}$ similar indicator is used in the literature on Norway. Seierstad and Opsahl (2011) show
} 
Following Ahern and Dittmar (2012) we aggregate individuals' characteristics at the board level and consider average values for the board. ${ }^{14}$ Table 1 presents summary statistics of the measures that we use for the above outcomes. We show average board characteristics. We consider together all types of boards: boards of directors, boards of statutory auditors and the alternative forms of governance for the very few existing cases (see Footnote 7 ). The table also shows the percentage of retained members, i.e. members of the board who were confirmed from the previous election. ${ }^{15}$

\subsection{Firm-level data}

We then collect firm-level data on the characteristics of and outcomes at each company (Ahern and Dittmar, 2012). This information, again, was not immediately available. We relied, when available, on data from Orbis-AIDA (Bureau van Dijk), which we integrated with data from Bankscope on banks. In the case of missing data, which was often, we hand collected the corporate documents available on the website of the Milan Stock Exchange or on the official budget balance sheets published on each company's website. We also collected the firm value measured by Tobin's Q from Datastream. The final dataset contains the following information for each company for the period 2010-2014: name, province of registered office, number of employees, production (thousands of euros), profits (thousands of euros), share of short-term and long-term debts, ROA, Tobin's Q, and asset, (thousands of euros) (data refer to end of December, when the budget is closed).

Sector data are also downloaded from Aida and harmonized to comply with the GICS classification of industrial sectors. We consider the following sectors: consumer discretionary, financial sector, industrials, and other minor sectors. ${ }^{16}$

that the introduction of gender quotas in Norway is associated with an increase in multiple positions, the so called 'golden skirt' phenomenon.

${ }^{14}$ The alternative would be to consider observations at the individual level. Our main results would not change.

${ }^{15}$ In the Appendix A1 we also provide summary statistics for the same variables at the individual level, separately by gender and by type of board.

${ }^{16}$ According to the GICS classification of sectors, companies in the consumer discretionary sector include automobiles and components, consumer durables and apparel, consumer services, media, and retailing; firms in industrials include those producing capital goods and offering professional and commercial services; the financial sector includes banks and companies providing 
Firm-level data will be used to assess the causal relationship between women's empowerment (through gender quotas) and the firm's economic and financial performance.

Table 2 presents summary statistics for the firms' outcomes.

\subsection{Stock market data}

Finally, we downloaded from Bloomberg the daily closing price of the FTSE MIB for the years 2009-2014. These data are used to answer three questions: first, what is the impact of women's empowerment (through gender quotas) on riskiness of the company (part II)? Second, what is the impact of the announcement of the introduction of the gender quota law on stock market prices (part III)? Third, what is the impact of gender quotas on the stock market at the board's elections (part IV)?

To sum up, our final dataset consists of a panel dataset over the years 20102014 including all Italian firms listed on the Milan Stock Exchange for which we have data on the composition of the board of directors, individual characteristics of board members, board election dates, financial indicators, and the daily closing price. To check for pre-reform conditions, individual characteristics of board members were also collected for the period 2007-2010 and the daily closing price collected for the period 2009-2010. We will also use data on 135 Spanish companies listed on the Madrid Stock Exchange as a control group in part III. From Comisión Nacional del Mercado de Valores, we collect information on the gender composition of the board of directors as of June 2011, from Orbis we collected financial and sector data and from Bloomberg we downloaded daily stock price data for these Spanish companies.

\section{Part I. How boards of directors change}

We start by analyzing the effects of the gender quota law on the individual characteristics of board of directors. Following Ahern and Dittmar (2012), we aggregate individual characteristics at the board level. We then evaluate the change

diversified financial services, insurance, and real estate. In our analysis, minor sectors include energy, health care, IT, materials, telecommunication services, and utilities. 
of board characteristics before and after the reform, taking into account the prereform trend. Understanding how boards change after the quota is important to reply to the conventional wisdom that gender quotas are associated to the entry of less-qualified individuals. Our analysis focuses on the level of education as the main characteristic that proxies members' competence. ${ }^{17}$ This is in line with Bianco et al. (2015) for the Italian context, Adams and Ragunathan (2015) for the U.S., and corresponds with the literature on the selection of politicians (Galasso and Nannicini, 2011). ${ }^{18}$ Nevertheless, the final "judge" of which characteristics may signal a positive attribute will be the reaction of the financial market (see Part IV).

\section{$5.1 \quad$ Methodology}

In the ideal evaluation setting of a natural experiment, only one random group of firms is subject to the reform in a given year (treated group), and the other firms are not subject to the reform in this year (control group). We would observe the outcomes in the treated group before and after the reform and compare them with those of the control group. Unfortunately, all Italian listed companies are subject to the law, and it is difficult to imagine a control group of firms similar to the listed ones and not subject to the law. However, we can exploit beforeafter reform changes for the same firm and we can observe outcomes/indicators in years before the reform to adjust for the time trend. Despite not being the perfect identification strategy, it nevertheless allows a very informative and demanding analysis. We also use a graphical analysis to support our identification.

Figure 2 shows the timeline of the implementation of the law and the board elections for the two cohorts of firms that we consider: as boards are renewed every three years, the first cohort changed boards in 2007, 2010, and 2013 and the second cohort in years 2008, 2011, and 2014. Thus, for each cohort, the first

\footnotetext{
${ }^{17}$ We do not consider CEO experience, not only because of the extremely low number of female directors and CEOs in listed companies before the law, but also because having more women in top leadership positions, and thus giving them the opportunity to acquire experience, is exactly the goal of the law. Indicators based on the evaluation of the profession (rather than of the education level) are also difficult to apply in this context, as board members do not come from all professional backgrounds.

${ }^{18}$ Note also that attracting better-educated people is considered an essential part of firms' business strategy and one of the main reasons behind the promotion of gender equality (see OECD, 2012).
} 
two elections (2007 and 2010 for the first cohort, 2008 and 2011 for the second) are not affected by the quota law, while the third election happens to be in the post-quota period. Thus, we can evaluate the impact of the reform on board characteristics by comparing the changes in the period 2007-2010 and the period 2010-2013 for the first cohort. Similarly, we compare the changes in the period 2008-2011 and in 2011-2014 for the second cohort. ${ }^{19}$

More precisely, starting from the first cohort, we perform an "adjusted beforeafter reform" evaluation design. We define $\beta$ as the impact of the reform on the characteristic $I$ of the board, according to the following formula:

$$
\beta=\left(\bar{I}_{t+3}-\bar{I}_{t}\right)-\left(\bar{I}_{t}-\bar{I}_{t-3}\right)
$$

where $\bar{I}$ is the average over the sample of boards of the characteristic under evaluation, and $t$ indicates the calendar year, with $t=2010$.

The assumption underlying our identification strategy is that, if the reform had not happened, $\left(\bar{I}_{t+3}-\bar{I}_{t}\right)$ would have been equal to $\left(\bar{I}_{t}-\bar{I}_{t-3}\right)$. The coefficient $\beta$ is estimated through the following equation:

$$
I_{i j t}=\alpha_{1}+\alpha_{2} \operatorname{second}_{j t}+\beta \text { second }_{j t} * \text { reform }_{j}+\varepsilon_{i j t}
$$

where $I_{i j t}$ refers to the characteristic of board $i$ (board of directors and board of auditors) of each firm in period $j(j=0,1$, where $j=1$ refers to the period 2010-2013 and $j=0$ refers to the period 2007-2010) and year $t(t=1$ refers to year 2013 if $j=1$ and to year 2010 if $j=0 ; t=0$ refers to year 2010 if $j=1$ and to year 2007 if $j=0$ ). Second is a dummy variable equal to 1 if the year is 2013 for the time period 2010-2013 $(j=1)$, or if the year is 2010 for the time period 2007-2010 $(j=0)$, and 0 otherwise. Reform is a dummy variable equal to 1 if the time period is 2010-2013 and 0 otherwise; $\varepsilon_{i j t}$ is a composite residual consisting of a board-specific fixed effect and a standard error term.

We replicate Regression 2 for the second cohort 2008-2011-2014, and together for the two cohorts of boards (2007-2010-2013 and 2008-2011-2014). Having two repeated cohorts of boards staggered over one year gives the opportunity

\footnotetext{
${ }^{19}$ In the Appendix A1 we provide an alternative identification strategy that exploits the existence of three random groups of firms with staggered board elections. Results are in line with what was obtained in this section.
} 
to compare what happened to cohort 2007-2010-2013 to cohort 2008-2011-2014. If the before-after estimated change (i.e. $\beta$ ) is similar across the two cohorts, we are reassured against the concern that time-varying unobservable variables may drive our results. Moreover, we check that the time-trend before the reform is the same for the two cohorts: for each characteristic under evaluation we estimate a regression coefficient for the time-trend before the reform, separately for the two cohorts, and test that they are not significantly different (95\% confidence interval).

The characteristics $I$ of each board under evaluation are: the share of women; whether the share of women exceeds the $20 \%$ initial threshold required by the law (yes or no); the presence of a female president (yes or no); the presence of a female CEO (yes or no); the share of board members with a university degree (all, and female and male separately); the share of board members with a graduate degree or MBA (all, and female and male separately); the share of board members with a foreign university degree (all, and female and male separately); the share of board members with a university degree in economics and business, in law, in engineering, in political science (all, female and male separately); the heterogeneity of the fields of study within the board; the share of board members older than 60 and 70 respectively (all, and female and male separately); the share of board members belonging to the family owners (all, and female and male separately); and the average number of board positions (all, and female and male separately).

\subsection{Results}

Table 13 presents our results. The first column shows the results of estimating Equation 2 for the cohort 2007-2010-2013, the second column for the cohort 20082011-2014, and the third column for both cohorts together. Not surprisingly, the reform is significantly associated with an increase of the share of women directors in all columns. Interestingly, the reform is also associated with an increase in the share of women on boards over the initial target of $20 \%{ }^{20}$ Thus, the reform has reached the goal of increasing female representation on boards. When we look

\footnotetext{
${ }^{20}$ As the law imposes to reach the closer higher rounded number, we have rounded up the non entire numbers.
} 
at the roles of members of the board, and distinguish between presidents and CEOs, we see an increase of the share of female presidents. For the cohort 20082011-2014 and for the full sample of boards, we also observe an increase in female CEOs. These results suggest that the reform increases women's empowerment beyond the simple numerical outcome.

Moving to our second group of outcome - education - the reform increases the share of members with a university degree and graduate studies. The result is significant for both the cohort 2008-2011-2014 and the full sample. This suggests that firms that have more time to adapt fully the change. Interestingly, the higher average level of education of board members after the reform is not only due to women, but, when concentrating on graduate studies, also to men: with the gender quota law, we find more men with higher education than before the law. Similarly, the second cohort and the full sample show an increase in board members, both men and women, who studied abroad. When we consider fields of study, a robust result is that after the reform there are more women with a degree in economics and business as well as in law, while for other fields results are not robust across all our cohorts. We do not find significant change in the Herfindahl index, which captures the heterogeneity of the board in terms of fields of study.

Our next indicator is age. Gender quotas are associated with lower age, by including younger women on boards: this effect is clear when we consider individuals over the age of 60 in the cohort 2007-2010-2013 and in the comprehensive group. For the same subgroups we find a significant decrease in board members older than 70. This reduction is driven by women. Note that in Italy board members over age 70 are not an exception: in the pre-quota period they were roughly $15 \%$ of board members. The reduction in age as a spillover effect of gender quotas is probably particularly meaningful in this context (see also Baltrunaite et al., 2015 , in the context of politics). As the average age of directors is high (around 55 in the period 2009-2011), lowering the age of directors can be interpreted as an outcome of a more balanced composition. To capture heterogeneity of the board by age, we also calculate the standard deviation of the age of all members of the boards and find that it is not significant.

Table 13 also shows that the gender quota reform is not associated with a significant change in the number of board members with a family relationship 
with the ownership. A major concern for the introduction of a gender quota law relates to the risk of appointing non-competent women (low-educated) linked to the family of the owners. The evidence in Table 13 seems to allay this concern.

Finally, we examine whether gender quotas increase the holding of multiple positions. This is another common concern when we consider the introduction of gender quotas: if quotas result in the appointment of the same few women to all boards, quotas are not able to reach their goal of giving opportunities to all qualified individuals, men and women, and they risk producing a reduction in the quality of corporate governance. Table 13 shows that the average number of positions held by individuals does not seem to show a clear, increasing pattern with the reform: it increases for the first cohort, while it does not significantly change for the second cohort and the comprehensive group. If we consider men and women separately, we observe an increase in the number of board positions held by men in the first cohort, and an increase in the number of positions held by women in the second and the comprehensive groups.

\subsection{Into the mechanism}

What is the mechanism driving the observed changes in board characteristics after the implementation of the gender quota law? This fundamental question does not have an easy answer. We do not claim to have the final answer, but we provide some evidence that a possible mechanism lies in the selection process, which changed dramatically after the introduction of quotas.

We focus on education and age, the two main variables where we have observed significant changes after quotas. We split our board members into three groups: retained, exiting, and new members. ${ }^{21}$ Table 4 reports data for the average characteristics for each group, comparing in panel A the first cohort of companies, the elections in 2010 (before quotas) and 2013 (after quotas) and, in panel B, the second cohort, the elections in 2011 (before quotas) and 2014 (after quotas). In the pre-reform situation, new members were not necessarily more educated than exiting ones, but rather the opposite. Exiting members were more educated than retained ones, if we consider those with a university degree, and

\footnotetext{
${ }^{21}$ We are aware that re-appointments may be constrained by factors that we do not consider (such as the number of previous appointments). These factors are, however, time-invariant, and thus should not bias our analysis.
} 
more educated than both new members and retained if we consider those with graduate education (panel A). The situation is completely different in 2013, when the new members are significantly more educated than both the exiting ones and the retained for both levels of education (panels A and B). It is not clear whether retained members are more educated than exiting ones: retention is probably based on different criteria. Certainly, the pre-quota evidence, in which retained members were significantly less educated than exiting ones (for both level of education in panel A and for the graduate level in panel B), disappears. If we compare directly the three groups in the different years, retained members after the reform are more educated than those before the reform (considering those with a university degree in panel $\mathrm{A}$ and those with a graduate degree in panel B). New members after the reform are more educated than new members before. When we consider male and female members separately, we note that new female members after the reform are always more educated than retained ones (who are, however, very few). Interestingly, new male members appointed after the reform are also always significantly more educated than both retained and exiting male members, thus suggesting that the selection process for males changes after the reform, and it leads to the appointment of more-educated men. These results provide evidence of a slightly negative selection process in place before the reform (with more educated members exiting the board), that is reversed after the reform. The reform induces a different, better selection of both female and male members.

Age follows a slightly different process: there is evidence that new members were significantly younger than retained and exiting members even before the reform, a fact that is confirmed after the reform. However, the reform seems to have accelerated the process. In fact, the percentage of new members older than 60 or 70 , males and females, is significantly lower after the reform for both cohorts. After the reform, new members are a lower share of older people than retained members (males and females) and, especially if we consider males, than exiting members.

These results are particularly meaningful in the Italian context, where female appointments before the introduction of the quota were mainly driven by family representation on the board (often of women with lower education who were also less engaged than men in running the business), rather than by selection based 
on merit (Bianco et al., 2015). Our findings suggest that the gender quota law has improved the overall selection process. This is due both to opening the field to women, who turn out to be highly educated, and to better selection of male members (i.e. less-educated men exit the board).

\subsection{Robustness analysis}

In this section we perform several robustness checks on our main analysis.

First, one might be concerned that the results of the "before-after" analysis we presented are driven by an omitted time-trend of the variables we considered. This concern is exacerbated by the fact that we do not have a control group, since the quota applies to all Italian listed companies, although in different periods. In Figures 3 and 4 we present four graphs that show the evolution of women's age and education over the period 2009-2014. The triangle shows the first cohort of firms (which renewed the board in years 2007, 2010, and 2013), and the square indicates the second cohort (which changed their boards in years 2008, 2011, and 2014). We also consider a third cohort of firms with board elections in 2009 and 2012, which is represented by the diamond marker. Note that this third cohort is never affected by the reform (see Figure 1). The graphs show a clear timetrend before the reform, and a spike in the value of the variables in 2013 and 2014, specifically after the introduction of the quota law. Figure 3 shows that, although the percentage of educated women is increasing over time, it increased dramatically after the introduction of the reform for firms that changed their board in 2013 and 2014. Similarly, in Figure 4, the percentage of female directors older than 60 and 70 is decreasing over time for all firms, while in 2013 and 2014 it decreased dramatically only for firms that changed their board under the new rule (square and triangle markers). Therefore, based on this graphical analysis, we are able to allay the concern that the presence of an omitted time-trend substantially drives our main results.

Second, we focus on different industrial sectors: consumer discretionary, financial sector, industrials and other minor sectors (see Footnote 16). One may be concerned given the fact that the introduction of the gender quota law overlaps with a period of economic crisis. Firms may decide to better select their

board members by appointing more-qualified individuals not as a result of the 
quota law, but as a reaction to stronger competition. However, if this is the case, we should observe differential effects by sectors, with sectors more affected by the economic crisis (for instance, the financial sector) showing, for example, a significant increase in the education level, while the other sectors should not. However, when we split our sample by sectors, we do not find any differential effect across sectors, thus showing that firms belonging to different sectors selected board members in a rather similar way. ${ }^{22}$

Third, we ensure that quotas are binding in most of our boards and that all effects remain if we exclude the few boards that already satisfied the required threshold in the pre-reform period (around 15-20\% of the sample, mainly boards of auditors). All our significant effects related to women's empowerment, education, and age are even stronger if we only consider boards that had no women in the pre-reform period ( $50 \%$ of the sample). ${ }^{23}$

Fourth, we also consider the dimension of the company and check whether our results are driven by either larger or smaller firms. We consider firms above and below the median value of assets in 2012, and run separate regressions for the two subgroups. Once again, our results do not differ between the two subgroups. ${ }^{24}$

Fifth, because the law applies to all board members, our analysis puts all type of boards together, mainly boards of directors and boards of statutory auditors. Our main results are robust to focusing only on boards of directors or boards of statutory auditors: the gender quota law reform induces higher education for members of the board, lower age and has no impact on family and multiple positions. However, when we focus on boards of directors only, we notice a very large and highly significant increase in the percentage of directors with a university degree or a graduate degree (both men and women) and a large and significant increase in the percentage of members who studied abroad (both men and women) for the 2008-2011-2014 subgroup, thus suggesting that the increase in the level of education of board members for the 2008-2011-2014 subgroup is mainly driven by the members of the board of directors. ${ }^{25}$

Finally, it could be the case that the quota law is associated with a different number of members of the board: companies may try to elude the law by reducing

\footnotetext{
${ }^{22}$ Results are available upon request.

${ }^{23}$ Results are available upon request.

${ }^{24}$ Results are available upon request.

${ }^{25}$ Results are available upon request.
} 
the number of directors on each board. Alternatively, they may increase the size of the board in order to keep all male members. We check that this does not happen significantly in Italy.

\section{Part II. The effects on performance}

In this section we turn to economic and financial outcomes and analyze the effects of women's empowerment on companies' performance. ${ }^{26}$ Following a standard literature (Ahern and Dittmar, 2012), we consider the following measures of firms' performance: number of employees, assets, production, profits, ROA, Tobin's Q, and short-term debts. We are aware that the time span after the quota law is still limited, and we can only consider short run effects. A large literature has identified low risk-aversion as a female trait (see Bertrand, 2011 for a review). To provide evidence in this direction, we also consider the impact of gender quotas on the riskiness of the company, a dimension that has not been addressed in the Norwegian context.

\subsection{Methodology}

In order to estimate the causal effect of women's presence on the boards on firms' outcomes, we employ an instrumental variable approach with fixed effects for firms and years.

We use data from 2010 to 2014 and regress the firm's outcome on the percentage of female directors on the board, which is instrumented with the dummy reform period. This variable also takes on value 1 in 2013 for firms that changed their board in 2013, thus being subject to the quota. In 2014 the variable takes on value 1 also for firms that changed their board in 2014, thus leaving in the control group firms that changed their board in 2015, which we called the "phase-in" group. As a second stage, we estimate the following equation:

$$
y_{i, t}=\alpha+\beta \text { percentage women director } s_{i, t}+\theta_{i}+\tau_{t}+\epsilon_{i, t}
$$

\footnotetext{
${ }^{26}$ For this analysis we drop the companies with a one-tier governance system (Monistico) to have a group of companies with a comparable corporate governance system, and we concentrate on the members of the board of directors (Consiglio di Amministrazione; see Footnote 7).
} 
where $y_{i, t}$ is the firm's outcome, represented by the number of employees, assets, production, profits, ROA, Tobin's Q and short-term debts, for each firm $i$ and year $t$, where $t$ goes from 2010 to 2014; percentage women director $s_{i, t}$ is the proportion of women on the board; $\theta_{i}$ and $\tau_{t}$ represent firm and year fixed effects respectively; $\epsilon_{i, t}$ is a random error with normal distribution; and $\beta$ is the parameter of interest.

To assess the relationship between women's empowerment and riskiness of the company, we regress the monthly volatility of stock prices on the percentage of female directors. We compute the monthly volatility as the monthly standard deviation in the stock price for each firm, using daily data from 2011 to 2014. We run the same regression as in Equation 3, where the outcome is represented by monthly volatility for firm $i$ in month $t$.

\subsection{Results}

The first stage regression in Table 5 shows that reform period is positively related to the share of female directors, and the coefficient is significant at the $1 \%$ level, thus showing that the reform dummy is a strong predictor for the percentage of women on the board. The results of the instrumental variable regression in Table 6 show that all the considered performance outcomes are not significantly (and hence, different from Norway, not negatively) affected by the proportion of women on the board.

Finally, in Table 7 we analyze whether women's empowerment is related to the riskiness of the company. The coefficient on the proportion of women directors is equal to -0.0092 and significant at the $1 \%$ level. Therefore, our evidence suggests that the proportion of women on the board is associated with a significant reduction in the volatility of stock prices, i.e. less riskiness of the company.

\subsection{Robustness analysis}

We perform several robustness checks of our analysis. First, it may be the case that the effect of the share of female directors on performance outcomes is nonlinear, namely that there is a differential effect at different thresholds of the share of female directors. To account for this possibility, we set several thresholds for the instrument reform period, setting these percentages at 5\%,10\%,15\%, and 
$20 \%$ (the latter is the threshold imposed by the quota law). We do not find any effect of these thresholds on performance measures, and thus we can exclude differential effects of the percentage of women directors at different thresholds on performance measures.

Second, we examine whether the negative effect of the share of female directors on the volatility of stock prices, which is the only significant effect obtained by the reform on outcomes, is driven by firms of particular industrial sectors. We perform separate regressions to find that the reduction in the monthly volatility is not driven by firms in the financial and consumer discretionary sectors, but rather by companies in the industrial and other minor sectors. We also examine whether the percentage of female directors has differential effects on stock price volatility in large firms relative to smaller firms. We run separate regressions distinguishing between firms with assets above and below the median value of assets in every year, and find that the reduction in stock price volatility is negative and significant in both groups. Therefore, we can conclude that there are no heterogeneous effects from the percentage of women directors in firms of different size.

\section{Part III. Stock market reactions to the announce- ment of the law}

As we consider listed companies, a natural way of evaluating the effects of the reform is to analyze the reaction of the stock market. In this section, we investigate the reaction of the Italian financial market to the announcement of the introduction of the quota law, while in the next section we concentrate on the date of board elections.

\subsection{Methodology}

Our analysis follows the identification strategy of Ahern and Dittmar (2012) and Nygaard (2011). Ahern and Dittmar (2012) use the "event study" technique to assess whether the Norwegian board quota law affects stock price data of Norwegian listed companies relative to U.S. and other Scandinavian companies (not Norwegian). These countries were chosen as a comparison group, as the debate on gender quotas had not yet hit the political agenda. 
We run the event study over the date of approval of the quota law on June 28, 2011; for robustness, we also repeat the analysis over the date of the approval of the draft of the law by the Italian Senate on March 15, 2011. These two dates were chosen after checking the news coverage of the quota law on Lexis-Nexis. In fact, for the first time on March 15, 2011, Italian public opinion was confronted with the concrete possibility of the enforcement of board gender quotas, and much emphasis was put on the debate, especially after International Women's Day on March 8. Similarly, on June 28, 2011, the final approval of the law hit the news and generated a significant debate in the political arena.

Closely following Ahern and Dittmar (2012), we consider for comparison the 135 Spanish companies listed on the Madrid Stock Exchange. ${ }^{27}$ We select Spain as a comparison group, because it is a Southern-European country similar to Italy with respect to cultural features and gender statistics. However, gender quotas in Spain were not in the spotlight in 2011, as the country chose to rely on voluntary recommendations back in 2007, and planned a first assessment of this policy for 2015 (Conde-Ruiz and Hoya, 2015).

We estimate abnormal returns around the event dates by using the standard Capital Asset Pricing Model (CAPM). In the field of law and economics, event studies using the CAPM are commonly used to assess the effects of regulation. The key focus of an event study is measuring the sample securities' mean and mean cumulative abnormal return around the time of an event (Kothari and Warner, 2004). We estimate the following equation:

$$
R_{i, t}=\alpha_{i}+\beta_{i, T} R_{m, t}+\epsilon_{i, t},
$$

where $R_{i, t}$ and $R_{m, t}$ represent, respectively, the daily stock return of firm $i$ at time $t$ and the market return. The market indexes are represented by the FTSE MIB for Italian firms and by the IBEX-30 for Spanish firms $R_{i, t}$ and $R_{m, t}$ were computed as

$$
R_{x, t}=\log \left(P_{x, t}\right)-\log \left(P_{x, t-1}\right)
$$

where $P_{x, t}$ represents the daily closing price of stock $x$ at time $t$, and $P_{x, t-1}$

\footnotetext{
${ }^{27}$ In the Appendices A2 and A3, we provide a different specification for the comparison group, exploiting the staggered board renewals within Italian companies. Results are similar to what we obtain in this section.
} 
represents the daily closing price of stock $x$ at time $t-1$. The parameter $\beta_{i, T}$ in equation 4 is estimated by regressing the stock return on the market return - FTSE MIB for Italy and IBEX-35 for Spain - over the corresponding estimation period (T). Consistent with previous literature (Rossi and Cebula, 2015, Adams, 2011), we use the (-250, -11) days estimation window for the estimation of Equation 4. The abnormal return (AR) for firm $i$ at time $t$ is computed as:

$$
A R_{i, t}=R_{i, t}-\left(\alpha_{i}+\beta_{i, T} R_{m, t}\right)
$$

while the cumulative abnormal returns $C A R_{i, T}$ for firm $i$ are the sum of the abnormal returns over the corresponding event window, from day $-T$ to day $T$, where $T \geq 1$ and $T \leq 5$ :

$$
C A R_{i, T}=\sum_{t=-T}^{T} A R_{i, t}
$$

Consistent with previous studies, we consider several event windows for robustness.

In our first specification, we follow Ahern and Dittmar (2012) and run a cross-section OLS regression that compares the sum of abnormal returns between Italy (treated) and Spain (control) at the day of the announcement of the law, interacting the dummy for treatment (Italian) with the gender composition of the board, and controlling for board size, the logarithm of assets and industrial sectors:

$$
\begin{array}{r}
C A R_{i}=\alpha+\beta \text { Italian }_{i}+\gamma \text { percentage women director }_{i}+ \\
\delta \text { Italian }_{i} * \text { percentage women director }_{i}+\phi \chi_{i}+\epsilon_{i}
\end{array}
$$

where Italian $_{i}$ is a dummy variable indicating the firm $i$ is Italian and percentage women director $s_{i}$ records its share of female directors at the announcement date. $\chi_{i}$ is a vector of control variables including the board size, the logarithm of assets and industrial sectors dummies. $\epsilon_{i}$ represents the error term. Standard errors are clustered at the firm level. The specification aims at assessing whether the announcement of the quota law has any significant impact on less gender-diverse Italian firms relative to less gender-diverse Spanish firms. 


\section{$7.2 \quad$ Results}

Table 8 shows in Panel A the results of the event study at the approval of the quota law on June 28, 2011. Italian firms experienced a significant drop in stock prices at the announcement of the approval of the law, with an average cumulative abnormal return of $-1.28 \%$, which is significantly different from zero. ${ }^{28}$ In order to examine whether the drop is driven by less gender-diverse firms, we compare the mean CARs of firms whose share of women directors was above the full sample median to CARs of firms that were below the median share of female directors at the approval of the quota law. The underlying idea is that of comparing two groups facing a different degree of strictness of the constraint imposed by the board gender quota. We find that the mean CARs are negative and significant for both groups, while the difference in the group means is close to zero and insignificant. These results appear to contradict the findings of Ahern and Dittmar (2012), who argued that gender quotas negatively affect stock prices, and the drop is larger for less-gender diverse firms due to the constraint imposed by the quota law. Our results are robust when looking at subgroups based on the average share of women on boards or the median number of women to be appointed by effect of the quota; similar results are also found when comparing firms that were already above the $20 \%$ target to firms that were not. As discussed in Section 7.1, if the financial market had anticipated the approval of the law at an earlier stage of the legislative procedure, we would be underestimating the market reaction to the introduction of the law. Therefore, in Panel B we performed the same event study at an earlier date, namely at the approval of the draft of the law by the Italian Senate on March 15, 2011. However, the results show that on March 15, 2011, the Italian stock market did not experience any significant movement in the average stock price, and thus the results on June 28,2011 , seem to adequately describe the response of the financial market to the introduction of the quota law.

As in Ahern and Dittmar (2012), we present additional evidence of the market reaction to the approval of the quota law and perform a difference-in-difference regression of the cumulative abnormal returns of Italian and Spanish firms on

\footnotetext{
${ }^{28}$ Note that a cumulative abnormal return equal to zero is aligned with the stock market performance, and thus what matters is the extent to which the cumulative abnormal return is different from zero.
} 
board characteristics and firm financial measures. The results in Table 9 show that on average Italian firms experienced significantly lower returns at the approval of the quota law on June 28, 2011 relative to Spanish firms. In fact, the coefficient on the Italian dummy is negative and significant, and ranges from $-2 \%$ to $-1.6 \%$. However, there was no significant difference in the stock price performance between more gender-diverse Italian and Spanish firms. Therefore, we are unable to cogently link the drop in the average stock price on June 28 to the introduction of the quota law. For robustness, we repeat the same analysis by looking at stock price performance on March 15, 2011, and as expected we find that there is no significant difference in the average stock price returns of Italian companies relative to Spanish companies.

Overall, we find that the Italian stock market had a negative reaction on the day of the announcement of the law. However since this reaction does not depend on how binding the quota is for the company, we do not have compelling evidence that this negative effect is due the announcement of the quota law. A further step to assess that there is no association between the quota law and the negative stock market effect is provided by looking at the day of board election. Is the negative effect on the day of the announcement (although not causally linked to the policy) confirmed on the day of board elections? This should be the case, if quotas are a negative, costly shock for the stock market. The next section will provide a different answer.

\section{Part IV. Stock market reactions to board elec- tions}

In this section we analyze the stock market reactions to board elections. Although Part III has documented a negative stock market effect on the day of the announcement of the law (though not clearly due to the policy), it may still be the case that, as boards change due to the introduction of women by the quota law (see Part I), if these changes are positively perceived by the market, the actual changes of the boards at the time of board elections translate into a positive effect on the stock market. 


\subsection{Methodology}

For all board elections of companies in the period 2011-2014 we run an event study over each board election and compute the ARs and CARs for different event windows. We consider the board election date and use the three groups of companies identified by the existence of staggered elections: pre-reform, phase-in, and post-reform.

We regress the resulting CARs on the quota election dummy and a variable that captures the distance from the threshold (i.e. $20 \%$ minus the share of women on the board before the considered election), to analyze whether the quota law and the changes in the share of women induced by the quota have any significant impact on companies' abnormal returns over the election days:

$$
C A R_{i}=\alpha+\beta \text { quota election }_{i}+\gamma \text { distance from threshold } d_{i}+\phi \chi_{i}+\epsilon_{i}
$$

where quota election $i$ is a dummy variable equal to 1 for elections with gender quotas and 0 otherwise, and distance from threshold $i$ is a continuous variable that represents the difference between the target threshold of $20 \%$ and the share of women on the board before the election. $\chi_{i}$ is a vector of control variables that includes industrial sector dummies and $\epsilon_{i}$ represents the error term.

\subsection{Results}

Table 10 shows the result of Regression 9 separately for the full sample of board elections (column 1) and the three subgroups of post-reform, phase-in and prereform elections. For each subgroup, we regress the computed CARs on board and firm characteristics, as described in Section 8.1. When looking at the full sample of board elections in column 1 we find that the dummy Quota election is not significant, suggesting that the constraint imposed by the law does not have any effect on stock price returns per se. However, the quota law seems to matter through the number of women to be appointed in order to comply with the law. In fact, our variable that captures the distance from the threshold is positive and highly significant in columns 1 and 2: a higher distance from the threshold, i.e. a larger number of women appointed in order to comply with the quota results in higher returns over the election period. This result is consistent 
with the fact that the introduction of gender quotas imposes a re-organization of the entire composition of the board (see Part I). We then split the sample and repeat the analysis to examine whether these results are driven by any of the three relevant subsamples: pre-reform, phase-in, and post-reform. When looking at the post-reform subsample, we find that the distance from the threshold is positive and significant at the $1 \%$ level: after the implementation of the law, it becomes clear that firms with fewer women on boards will have to make more substantial changes to their board composition in order to comply with the quota target. These firms turn out to have higher returns.

In Table A5 we examine whether the election of board members with the characteristics considered in Part I have any impact per se on stock market returns. Considering the pre-reform period in years not very far from the implementation of the law (2009-2011), but not influenced by the law, ${ }^{29}$ and controlling for board size and industrial sector (see also Adams, 2012), we regress CARs at board election for the usual 5-day window on the board member characteristics identified in Part I. We find that a larger share of members with a university degree and a smaller share of members older than 60 are significantly associated with better stock market performance. In other words, the elections of boards with more educated and younger members were associated, even in absence of the quota law, with better returns. Thus, the positive effect of the quota law on stock market returns shown in Table 10 is in line with the changes induced by the quota law on the board, mainly the higher education and lower age of board members (see Part I), which are positively received by the market. Table A5 also supports the interpretation of higher education and lower age as a signal of quality, something on which we have been agnostic throughout the paper. ${ }^{30}$ In fact, as we are considering listed companies, what really matters is the reaction of the financial market. If the stock market reacts positively to a given characteristic, as it turns out to be the case with more education and lower age, we can interpret this characteristic as being associated with quality.

\footnotetext{
${ }^{29}$ As Part I has proved that these characteristics are endogenous to the quota law, to understand how they are perceived by the stock market, we have to rely on before-reform elections.

${ }^{30}$ The relationship between age and the quality of decision-makers is indeed not obvious: on one side younger directors have a more active style of leadership, they are more likely to promote structural changes, and bring more creativity (Wiersema and Bantel, 1992; Wegge and Schmidt, 2009); on the other side they have less experience. As for education, see Part I and Footnote 13.
} 


\section{Discussion and Conclusions}

We have analyzed the effects of the introduction of a gender quota law on boards of listed Italian companies according to several dimensions: the change of boards' characteristics, the effects on firms' performance, and the stock market reaction to the announcement of the law and to board elections. We show that quotas are associated with a larger share of women directors, well above the required threshold, with higher education levels of all members of the board and lower ages. These results suggest that the gender quota law has introduced a new selection process for board members, which changed the composition of the boards. Changes may be costly, at least in the short run. However, we are able to reject the existence of a negative impact of gender quotas on economic performance a crucial concern when talking about the introduction of quotas. We also find that women's empowerment is linked to a lower variability of stock market risks. As the policy became law in 2012, it is probably still too early to provide a final answer on the effects on the changes in board composition on firms' results. However, we find that there is a positive reaction of the stock market at board elections. $^{31}$

Our results for the Italian case challenge what we have learnt from the previous Norwegian case, mainly that the stock market had a negative reaction to the law and performance (measured by Tobin's Q) decreased. How then, do we reconcile our results with those of Norway? Table 11 summarizes the status quo of boards of directors characteristics before the reform in Italy and Norway. Norway presents a clearly higher level of education of board members in the period preceding the reform compared to Italy. Moreover, it presents a lower average age of board members. In both cases, the level of education increases after the introduction of the quota (Ahern and Dittmar, 2012), ${ }^{32}$ while the change in age appears to be stronger in the Italian case, where we have shown an overall decrease of the

\footnotetext{
${ }^{31}$ Another unintended consequence of the Norwegian law is the delisting of companies (Bohern and Staubo, 2014). We do not find evidence of this effect for the Italian case: 215 companies were listed in 2010 and remained listed in 2013, 57 were listed in 2010 and are not listed in 2013, and 28 are listed in 2013 and were not in 2010.

${ }^{32}$ Ahern and Dittmar (2012) highlight the role of previous experience as CEO, while we concentrate on the role of education, because the share of Italian women with CEO experience is close to zero, and thus the effect would be quite mechanical. We thus consider education a more interesting characteristic, as explained in Part I.
} 
share of older members. We propose two arguments to understand the different mechanisms that may characterize Norway and Italy: the status quo and the selection. In Norway, the status quo before the reform was less critical than in Italy. Moreover, the reform imposed an immediate jump up to $40 \%$ in female representation. In the Italian context, instead, the status quo was less favorable to qualified people. The gradualism of the Italian reform may have helped firms to select the appropriate candidates. The starting assumption of Ahern and Dittmar (2012) is that firms know who the best members are for their performance and what characteristics they should have. By this argument, these characteristics correspond to those of the retained members, which are freely chosen by the firm. Thus, the farther the new members are from the characteristics of the retained ones (a fact which is very clear for women), the more likely it is that the firm will incur in losses. We question the initial assumption, and let the market decide which characteristics are associated with better performance (see Table A5). It turns out that these are higher education and lower age. In Section 5 we find that in the pre-reform period, the selection process for Italian boards was not oriented towards merit (see also Bianco et al., 2015): exiting members were often more educated than new and retained ones. After the quota law, instead, the selection process becomes more merit-oriented: both new female and male members were more educated and younger than exiting and retained ones. If we follow Ahern and Dittmar's (2012) argument and we compare directly the characteristics of new female members and exiting male members to understand the effects of the changes on the overall composition of the board, we find that new female members have a higher level of education (both university and graduate) and are younger than exiting men. Thus, this substitution between males and females increases the qualifications of board members (see Table 8). This is probably why drops in share prices are not found in the Italian case.

We suggest that our results are consistent with gender quotas inducing a beneficial restructuring of the board that is positively received by the market. This is in line with what has been found in the context of politics by Baltrunaite et al. (2014) and Besley et al. (2013). Our argument is supported by some interesting additional evidence. During the discussion around the introduction of the law, two facts rapidly became clear: first, the law has the potential to threaten the so-called "old-boys club", which dominated boards of directors prior 
to the introduction of the quota law, not necessarily because of their competence. Second, competent women are abundant: several lists with thousands of CVs of board-ready women were collected by women's associations, institutions, and business schools (see Profeta et al., 2014). Our results suggest that gender quotas may be a means to exploiting abundant unused female talent. The reaction of the market follows: quotas are not necessarily increasing the number of less-qualified directors, who are likely to perform worse, rather they may stimulate a beneficial restructuring of the ruling class.

As other countries, such as France and Germany, have recently introduced board gender quotas future studies will assess whether the results obtained for the Italian case are confirmed in other contexts. Further analyses are also needed to investigate whether the stock market reactions and changes in performance are persistent over time, and whether the new selection process initiated by the introduction of gender quotas will survive when quotas, which are temporary, are no longer in force. 


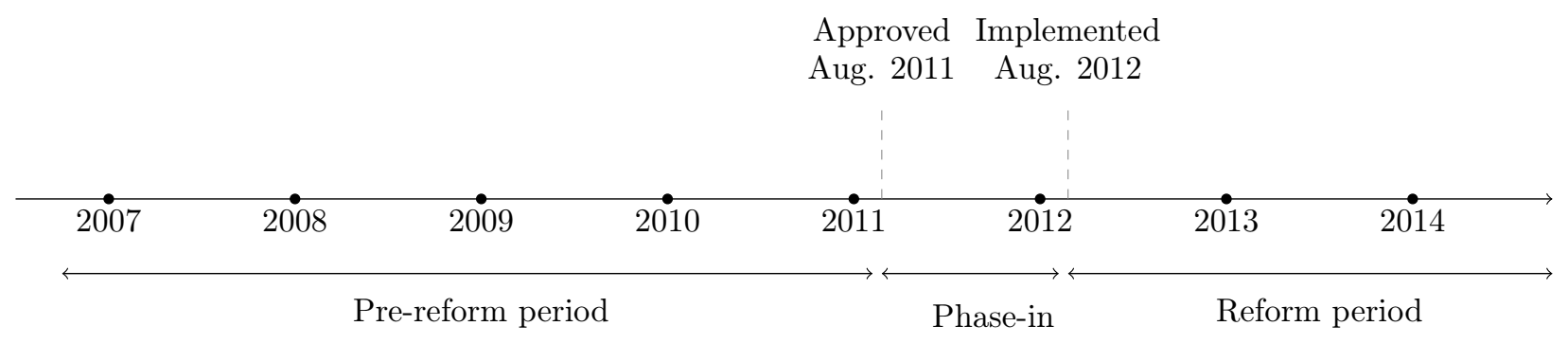

Figure 1: Timeline of implementation of the gender quota law

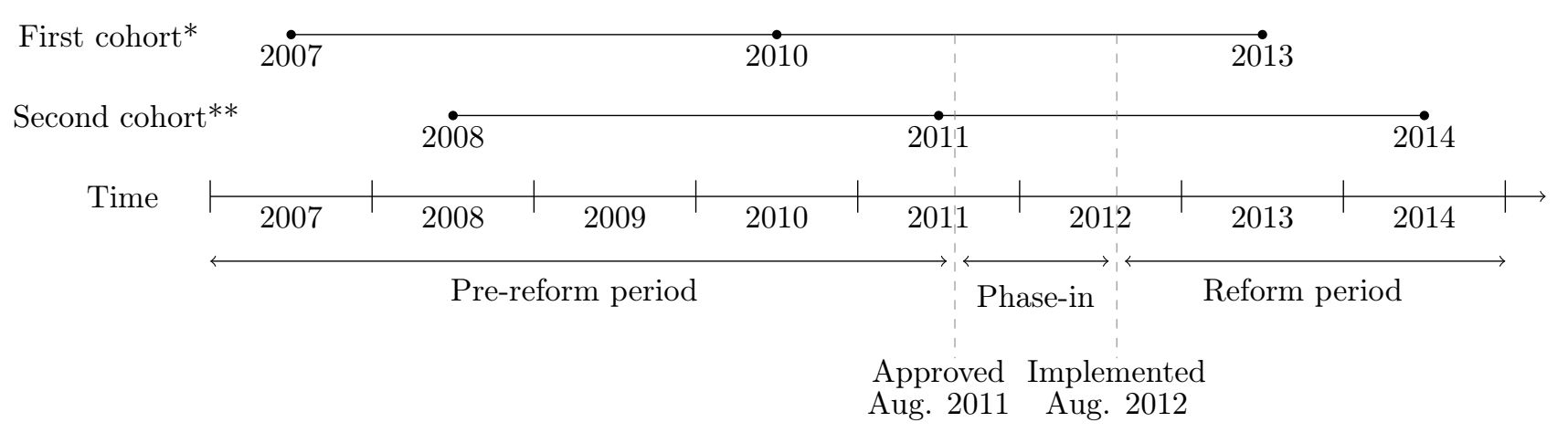

Figure 2: Timeline of board elections

Notes: The figure represents the timeline of the implementation of the law (on the time axis) and the timing of board elections.

*Board elections in years 2007, 2010, and 2013, from April to June.

**Board elections in years 2008, 2011, and 2014, from April to June. 
Table 1: Summary statistics: board characteristics

\begin{tabular}{|c|c|c|c|c|c|c|c|}
\hline & & 2009 & 2010 & 2011 & 2012 & 2013 & 2014 \\
\hline \multicolumn{8}{|l|}{ Women's empowerment } \\
\hline \multirow[t]{3}{*}{ Number of members } & & 6.84 & 6.76 & 6.72 & 6.67 & 6.60 & 6.94 \\
\hline & Women & 0.44 & 0.49 & 0.58 & 0.80 & 1.19 & 1.50 \\
\hline & Men & 6.40 & 6.27 & 6.14 & 5.86 & 5.41 & 5.44 \\
\hline Share of women $(\%)$ & & 6.67 & 7.39 & 8.29 & 11.80 & 18.15 & 22.12 \\
\hline More than $20 \%$ of women $(\%)$ & & 1.52 & 1.65 & 2.29 & 3.15 & 8.12 & 11.24 \\
\hline Female president & & 3.55 & 3.07 & 3.43 & 3.83 & 6.04 & 1.19 \\
\hline Female CEO & & 6.53 & 6.88 & 6.19 & 5.70 & 5.42 & 8.70 \\
\hline \multicolumn{8}{|l|}{ Education } \\
\hline \multirow[t]{3}{*}{$\%$ university degree } & All & 78.63 & 80.84 & 82.88 & 82.97 & 84.62 & 84.84 \\
\hline & Women & 22.98 & 26.75 & 31.89 & 43.73 & 58.10 & 68.52 \\
\hline & Men & 79.15 & 81.17 & 83.08 & 82.77 & 84.41 & 83.75 \\
\hline \multirow[t]{3}{*}{$\%$ graduate degree } & All & 5.11 & 5.28 & 5.41 & 5.14 & 5.37 & 6.98 \\
\hline & Women & 2.89 & 2.50 & 3.30 & 3.75 & 5.91 & 9.51 \\
\hline & Men & 5.05 & 5.27 & 5.33 & 5.10 & 5.09 & 5.90 \\
\hline Field diversity & All & 0.66 & 0.66 & 0.66 & 0.67 & 0.67 & 0.65 \\
\hline \multirow[t]{3}{*}{$\%$ study abroad } & All & 2.30 & 2.30 & 2.40 & 2.89 & 2.85 & 4.04 \\
\hline & Women & 2.30 & 2.20 & 2.32 & 2.63 & 2.48 & 3.16 \\
\hline & Men & 0.76 & 1.12 & 1.68 & 2.82 & 3.21 & 5.45 \\
\hline \multirow[t]{3}{*}{$\%$ degree in economics } & All & 54.64 & 56.71 & 58.38 & 59.54 & 60.81 & 59.69 \\
\hline & Women & 13.75 & 16.49 & 19.47 & 27.91 & 37.72 & 45.57 \\
\hline & Men & 54.98 & 56.89 & 58.45 & 59.51 & 61.04 & 58.79 \\
\hline \multirow[t]{3}{*}{$\%$ degree in law } & All & 10.11 & 10.22 & 10.39 & 10.07 & 10.81 & 11.54 \\
\hline & Women & 3.41 & 3.85 & 4.57 & 6.64 & 9.60 & 11.96 \\
\hline & Men & 10.04 & 10.13 & 10.34 & 9.83 & 10.41 & 10.95 \\
\hline \multirow[t]{3}{*}{$\%$ degree in political science } & All & 1.97 & 2.20 & 2.47 & 2.19 & 2.09 & 2.31 \\
\hline & Women & 1.10 & 1.14 & 1.98 & 1.86 & 2.23 & 2.19 \\
\hline & Men & 2.10 & 2.37 & 2.53 & 2.21 & 2.09 & 2.34 \\
\hline \multirow[t]{3}{*}{$\%$ degree in engineering } & All & 6.63 & 6.88 & 7.00 & 6.50 & 6.30 & 6.19 \\
\hline & Women & 1.02 & 1.42 & 1.89 & 2.57 & 2.60 & 2.50 \\
\hline & Men & 6.88 & 7.14 & 7.37 & 6.92 & 7.00 & 7.26 \\
\hline \multicolumn{8}{|l|}{ Age } \\
\hline \multirow[t]{3}{*}{$\%$ older than 60} & All & 38.05 & 38.28 & 37.02 & 39.46 & 36.81 & 35.23 \\
\hline & Women & 75.25 & 72.89 & 67.07 & 59.99 & 58.55 & 31.59 \\
\hline & Men & 30.72 & 39.25 & 37.62 & 42.23 & 41.71 & 42.30 \\
\hline \multirow[t]{2}{*}{$\%$ older than 70} & All & 15.79 & 15.28 & 14.12 & 17.42 & 15.81 & 14.04 \\
\hline & Women & 70.60 & 67.57 & 61.68 & 50.33 & 33.90 & 23.38 \\
\hline
\end{tabular}


Table 1: Summary statistics: board characteristics

\begin{tabular}{lrrrrrrr}
\hline & & 2009 & 2010 & 2011 & 2012 & 2013 & 2014 \\
\hline \hline Family ties & Men & 15.95 & 15.77 & 14.94 & 18.95 & 17.93 & 17.12 \\
\hline \% family members & & & & & & & \\
& All & 4.38 & 4.35 & 4.31 & 6.76 & 6.31 & 6.83 \\
& Women & 4.75 & 4.54 & 4.67 & 7.38 & 6.77 & 6.84 \\
& Men & 3.95 & 3.92 & 4.03 & 6.29 & 6.10 & 6.69 \\
\hline Multiple positions & & & & & & & \\
\hline Average number of positions & All & 1.45 & 1.37 & 1.26 & 1.27 & 1.31 & 1.28 \\
& Women & 1.31 & 1.23 & 1.13 & 1.16 & 1.22 & 1.22 \\
& Men & 1.46 & 1.38 & 1.28 & 1.29 & 1.33 & 1.29 \\
\hline Retained members & & & & & & & \\
\hline \% retained & All & & & & 50.21 & 47.85 & 49.01 \\
& Women & & & & 16.93 & 17.14 & 19.73 \\
& Men & & & & 52.21 & 52.20 & 55.45 \\
\hline Number of boards & & 394 & 423 & 437 & 444 & 480 & 436 \\
Number of firms & & 199 & 218 & 226 & 228 & 240 & 230 \\
\hline
\end{tabular}

Notes: Averages of average board characteristics of Italian listed companies over the period 2009-2014. 
Table 2: Summary statistics: firm characteristics

\begin{tabular}{|c|c|c|c|c|c|}
\hline & 2010 & 2011 & 2012 & 2013 & 2014 \\
\hline Log(employees) & 5.42 & 5.41 & 5.40 & 5.37 & 5.29 \\
\hline Log(production) & 10.76 & 10.76 & 10.67 & 10.66 & 10.71 \\
\hline Log(profits) & 9.73 & 9.46 & 9.39 & 9.38 & 9.53 \\
\hline $\log ($ assets $)$ & 13.03 & 13.04 & 13.04 & 13.05 & 13.01 \\
\hline $\mathrm{ROA}$ & -0.10 & -0.76 & -2.72 & -2.12 & -0.35 \\
\hline Tobin's Q & 0.90 & 0.94 & 0.97 & 0.79 & 0.83 \\
\hline Short-term debt & 0.69 & 0.64 & 0.63 & 0.69 & 0.67 \\
\hline Number of firms & 243 & 243 & 243 & 243 & 243 \\
\hline
\end{tabular}

Notes: Averages of firm characteristics of Italian listed companies over the period 2010-2014. 
Table 3: Effect on board characteristics

\begin{tabular}{|c|c|c|c|c|}
\hline & & $\begin{array}{c}\text { Boards changed in } \\
2007-2010-2013 \\
(1) \\
\end{array}$ & $\begin{array}{c}\text { Boards changed in } \\
\text { 2008-2011-2014 } \\
(2) \\
\end{array}$ & $\begin{array}{c}\text { All boards } \\
2007-2014 \\
(3) \\
\end{array}$ \\
\hline \multicolumn{5}{|l|}{ Women's empowerment } \\
\hline Share of women & & $\begin{array}{c}17.997^{* * *} \\
(1.286)\end{array}$ & $\begin{array}{c}15.896^{* * *} \\
(1.516)\end{array}$ & $\begin{array}{c}16.991 * * * \\
(0.988)\end{array}$ \\
\hline More than $20 \%$ of women & & $\begin{array}{c}0.152^{* * *} \\
(0.285)\end{array}$ & $\begin{array}{c}0.132^{* * *} \\
(0.035)\end{array}$ & $\begin{array}{c}0.142^{* * *} \\
(0.022)\end{array}$ \\
\hline Female president & & $\begin{array}{c}0.051^{* * *} \\
(0.018)\end{array}$ & $\begin{array}{c}0.242^{* * *} \\
(0.042)\end{array}$ & $\begin{array}{c}0.142^{* * *} \\
(0.022)\end{array}$ \\
\hline Female CEO & & $\begin{array}{c}0.018 \\
(0.031) \\
\end{array}$ & $\begin{array}{c}0.132^{* * *} \\
(0.043) \\
\end{array}$ & $\begin{array}{c}0.074^{* * *} \\
(0.027) \\
\end{array}$ \\
\hline \multicolumn{5}{|l|}{ Education } \\
\hline \multirow[t]{3}{*}{$\%$ university degree } & All & $\begin{array}{c}2.928 \\
(1.948)\end{array}$ & $\begin{array}{l}4.239^{* *} \\
(1.716)\end{array}$ & $\begin{array}{c}3.556^{* * *} \\
(1.304)\end{array}$ \\
\hline & Women & $\begin{array}{c}40.135^{* * *} \\
(4.516)\end{array}$ & $\begin{array}{c}39.652^{* * *} \\
(4.838)\end{array}$ & $\begin{array}{c}39.903^{* * *} \\
(3.297)\end{array}$ \\
\hline & Men & $\begin{array}{c}3.136 \\
(1.977)\end{array}$ & $\begin{array}{c}1.209 \\
(1.864)\end{array}$ & $\begin{array}{c}2.213 \\
(1.363)\end{array}$ \\
\hline \multirow[t]{3}{*}{$\%$ graduate degree } & All & $\begin{array}{c}1.400 \\
(0.896)\end{array}$ & $\begin{array}{c}7.149^{* * *} \\
(1.235)\end{array}$ & $\begin{array}{c}4.154^{* * *} \\
(9.767)\end{array}$ \\
\hline & Women & $\begin{array}{c}5.404^{* * *} \\
(1.600)\end{array}$ & $\begin{array}{c}12.692^{* * *} \\
(2.757)\end{array}$ & $\begin{array}{c}8.895^{* * *} \\
(1.577)\end{array}$ \\
\hline & Men & $\begin{array}{c}1.333 \\
(1.095)\end{array}$ & $\begin{array}{c}3.684^{* * *} \\
(0.919)\end{array}$ & $\begin{array}{c}2.459^{* * *} \\
(0.721)\end{array}$ \\
\hline
\end{tabular}


Table 3: Effect on board characteristics

\begin{tabular}{|c|c|c|c|c|}
\hline & & $\begin{array}{c}\text { Boards changed in } \\
2007-2010-2013 \\
(1) \\
\end{array}$ & $\begin{array}{c}\text { Boards changed in } \\
\text { 2008-2011-2014 } \\
(2) \\
\end{array}$ & $\begin{array}{c}\text { All boards } \\
2007-2014 \\
(3) \\
\end{array}$ \\
\hline \multirow[t]{6}{*}{ \% study abroad } & All & 0.612 & $3.523^{* * *}$ & $2.006^{* * *}$ \\
\hline & & $(0.441)$ & $(1.058)$ & $(0.562)$ \\
\hline & Women & 1.768 & $7.582^{* * *}$ & $4.553^{* * *}$ \\
\hline & & $(1.317)$ & $(1.695)$ & $(1.074)$ \\
\hline & Men & 0.273 & $1.271^{*}$ & $0.751^{*}$ \\
\hline & & $(0.447)$ & $(0.729)$ & $(0.421)$ \\
\hline \multirow[t]{6}{*}{$\%$ degree in economics } & All & 1.083 & $4.197^{* *}$ & $2.574^{*}$ \\
\hline & & $(2.081)$ & $(1.922)$ & $(1.422)$ \\
\hline & Women & $25.683^{* * *}$ & $34.579^{* * *}$ & $30.465^{* * *}$ \\
\hline & & $(4.220)$ & $(4.349)$ & $(3.030)$ \\
\hline & Men & 0.774 & -0.672 & 0.082 \\
\hline & & $(2.310)$ & $(1.964)$ & $(1.530)$ \\
\hline \multirow[t]{6}{*}{$\%$ degree in law } & All & $2.104^{*}$ & 0.538 & $1.354^{*}$ \\
\hline & & $(1.180)$ & $(1.130)$ & $(0.819)$ \\
\hline & Women & $8.283^{* * *}$ & $5.806^{* * *}$ & $7.096^{* * *}$ \\
\hline & & $(2.165)$ & $(2.125)$ & $(1.518)$ \\
\hline & Men & 2.219 & 0.360 & 1.329 \\
\hline & & $(1.437)$ & $(1.214)$ & $(0.948)$ \\
\hline \multirow[t]{2}{*}{ Field diversity } & All & -0.009 & -0.016 & -0.013 \\
\hline & & $(0.017)$ & $(0.018)$ & $(0.012)$ \\
\hline \multicolumn{5}{|l|}{ Age } \\
\hline \multirow[t]{2}{*}{$\%$ older than 60} & All & $-7.944 * * *$ & -2.686 & $-5.426^{* * *}$ \\
\hline & & $(2.390)$ & $(2.646)$ & $(1.778)$ \\
\hline
\end{tabular}


Table 3: Effect on board characteristics

\begin{tabular}{|c|c|c|c|c|}
\hline & & $\begin{array}{c}\text { Boards changed in } \\
2007-2010-2013 \\
(1) \\
\end{array}$ & $\begin{array}{c}\text { Boards changed in } \\
2008-2011-2014 \\
(2) \\
\end{array}$ & $\begin{array}{c}\text { All boards } \\
2007-2014 \\
(3) \\
\end{array}$ \\
\hline \multirow{5}{*}{$\%$ older than 70} & Women & $\begin{array}{c}-45.455^{* * *} \\
(4.433)\end{array}$ & $\begin{array}{c}-31.245^{* * *} \\
(5.349)\end{array}$ & $\begin{array}{c}-38.649^{* * *} \\
(3.457)\end{array}$ \\
\hline & Men & $\begin{array}{l}-1.458 \\
(2.616)\end{array}$ & $\begin{array}{c}3.427 \\
(2.883)\end{array}$ & $\begin{array}{l}-0.882 \\
(1.939)\end{array}$ \\
\hline & All & $\begin{array}{c}-4.817^{* *} \\
(2.141)\end{array}$ & $\begin{array}{l}-0.495 \\
(2.207)\end{array}$ & $\begin{array}{l}-2.747^{*} \\
(1.537)\end{array}$ \\
\hline & Women & $\begin{array}{c}-49.040^{* * *} \\
(4.588)\end{array}$ & $\begin{array}{c}-36.044^{* * *} \\
(4.922)\end{array}$ & $\begin{array}{c}-42.816^{* * *} \\
(3.363)\end{array}$ \\
\hline & Men & $\begin{array}{l}-3.052^{*} \\
(2.330)\end{array}$ & $\begin{array}{c}2.260 \\
(2.445)\end{array}$ & $\begin{array}{l}-0.507 \\
(1.688)\end{array}$ \\
\hline Standard deviation of age & All & $\begin{array}{c}0.512 \\
(0.498)\end{array}$ & $\begin{array}{l}-0.284 \\
(0.365)\end{array}$ & $\begin{array}{c}0.129 \\
(0.299)\end{array}$ \\
\hline \multicolumn{5}{|l|}{ Family ties } \\
\hline \multirow[t]{3}{*}{$\%$ family ties within the board } & All & $\begin{array}{l}-0.001 \\
(0.957)\end{array}$ & $\begin{array}{c}0.223 \\
(0.654)\end{array}$ & $\begin{array}{c}0.106 \\
(0.582)\end{array}$ \\
\hline & Women & $\begin{array}{c}0.000 \\
(1.741)\end{array}$ & $\begin{array}{l}-2.015 \\
(1.763)\end{array}$ & $\begin{array}{l}-0.965 \\
(1.238)\end{array}$ \\
\hline & Men & $\begin{array}{c}0.873 \\
(1.095)\end{array}$ & $\begin{array}{c}0.763 \\
(0.532)\end{array}$ & $\begin{array}{c}0.821 \\
(0.624)\end{array}$ \\
\hline \multicolumn{5}{|l|}{ Multiple positions } \\
\hline \multirow[t]{2}{*}{ Average number of positions } & All & $\begin{array}{c}0.089^{* *} \\
(0.038)\end{array}$ & $\begin{array}{l}-0.018 \\
(0.055)\end{array}$ & $\begin{array}{c}0.383 \\
(0.335)\end{array}$ \\
\hline & Women & 0.055 & $0.214^{* *}$ & $0.141^{* *}$ \\
\hline
\end{tabular}


Table 3: Effect on board characteristics

\begin{tabular}{cccc}
\hline & $\begin{array}{c}\text { Boards changed in } \\
\text { 2007-2010-2013 } \\
(1)\end{array}$ & $\begin{array}{c}\text { Boards changed in } \\
\text { 2008-2011-2014 } \\
(2)\end{array}$ & $\begin{array}{c}\text { All boards } \\
2007-2014 \\
(3)\end{array}$ \\
\hline \hline \multirow{3}{*}{ Men } & $(0.099)$ & $(0.100)$ & $(0.070)$ \\
& $0.101^{* *}$ & -0.084 & 0.013 \\
& $(0.042)$ & $(0.057)$ & $(0.035)$ \\
\hline
\end{tabular}

Notes: The table reports the coefficients of the interaction term of the "before-after" adjusted OLS regression, where the dependent variable is represented by each of the variables reported in the table. Column 1 shows the results for boards with election date in 2007-2010-2013; column 2 the results for the subgroup 2008-2011-2014 and column 3 the results for all boards together. In column 1 we run the following regression: $I_{i j t}=\alpha_{1}+\alpha_{2} \operatorname{second}_{t}+\beta$ second $_{t} *$ reform $_{j}+\varepsilon_{i j t}$ where $I_{i j t}$ refers to the characteristic of board $i$ (board of director and board of auditors) of each firm in period $j(j=0,1$, where $j=1$ refers to the period 2010-2013 and $j=0$ refers to the period 2007-2010) and year $t(t=1$ refers to year 2013 if $j=1$ and to year 2010 if $j=0 ; t=0$ refers to year 2010 if $j=1$ and to year 2007 if $j=0$ ). In column 2 we repeat the same regression for the cohort 2008-2011-2014. In column 3 we run the regression for all boards together. The coefficient's standard error is reported in parenthesis * Significant at $10 \%$;* $5 \%$;** $1 \%$ 
Table 4: Characteristics of retained, exiting, and new members

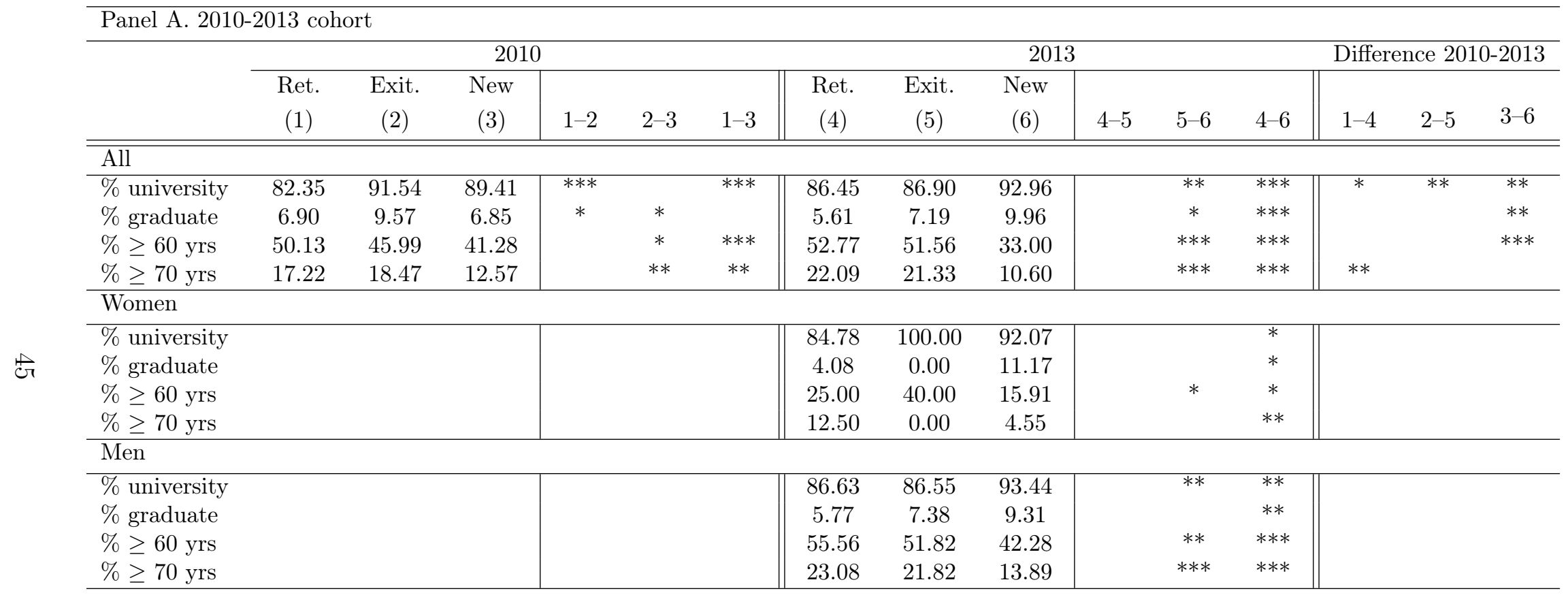




\begin{tabular}{|c|c|c|c|c|c|c|c|c|c|c|c|c|c|c|c|}
\hline \multicolumn{16}{|c|}{ Panel B. 2011-2014 cohort } \\
\hline & \multicolumn{6}{|c|}{2011} & \multicolumn{6}{|c|}{2014} & \multicolumn{3}{|c|}{ Difference 2011-2014 } \\
\hline & $\begin{array}{l}\text { Ret. } \\
(1)\end{array}$ & $\begin{array}{c}\text { Exit. } \\
(2)\end{array}$ & $\begin{array}{c}\text { New } \\
(3)\end{array}$ & $1-2$ & $2-3$ & $1-3$ & $\begin{array}{l}\text { Ret. } \\
(4)\end{array}$ & $\begin{array}{c}\text { Exit. } \\
(5)\end{array}$ & $\begin{array}{c}\text { New } \\
(6)\end{array}$ & $4-5$ & $5-6$ & $4-6$ & $1-4$ & $2-5$ & $3-6$ \\
\hline \multicolumn{16}{|l|}{ All } \\
\hline$\%$ university & 87.75 & 87.70 & 92.41 & & $* *$ & $* *$ & 89.51 & 89.47 & 94.10 & & $* *$ & $* *$ & & & \\
\hline$\%$ graduate & 3.31 & 9.01 & 6.75 & $* * *$ & & $* *$ & 5.51 & 3.17 & 20.68 & $*$ & $* * *$ & $* * *$ & $*$ & $* *$ & $* * *$ \\
\hline$\% \geq 60 \mathrm{yrs}$ & 46.11 & 46.77 & 33.88 & & $* * *$ & $* * *$ & 45.77 & 41.74 & 27.08 & & $* * *$ & $* * *$ & & & $* *$ \\
\hline$\% \geq 70$ yrs & 20.83 & 18.28 & 8.79 & & $* * *$ & $* * *$ & 20.64 & 16.06 & 9.37 & $*$ & $* *$ & $* * *$ & & & \\
\hline \multicolumn{16}{|l|}{ Women } \\
\hline$\%$ university & & & & & & & 90.91 & 88.24 & 93.91 & & & & & & \\
\hline$\%$ graduate & & & & & & & 12.24 & 11.76 & 27.82 & & * & ** & & & \\
\hline$\% \geq 60 \mathrm{yrs}$ & & & & & & & 22.98 & 5.88 & 12.50 & * & & ** & & & \\
\hline$\% \geq 70$ yrs & & & & & & & 2.09 & 0.00 & 2.68 & & & & & & \\
\hline \multicolumn{16}{|l|}{ Men } \\
\hline$\%$ university & & & & & & & 89.32 & 89.58 & 94.22 & & $*$ & $* *$ & & & \\
\hline$\%$ graduate & & & & & & & 4.52 & 2.45 & 16.11 & & $* * *$ & $* * *$ & & & \\
\hline$\% \geq 60 \mathrm{yrs}$ & & & & & & & 49.09 & 44.78 & 36.36 & & $* *$ & $* * *$ & & & \\
\hline$\% \geq 70 \mathrm{yrs}$ & & & & & & & 33.43 & 17.41 & 13.64 & $*$ & & $* * *$ & & & \\
\hline
\end{tabular}




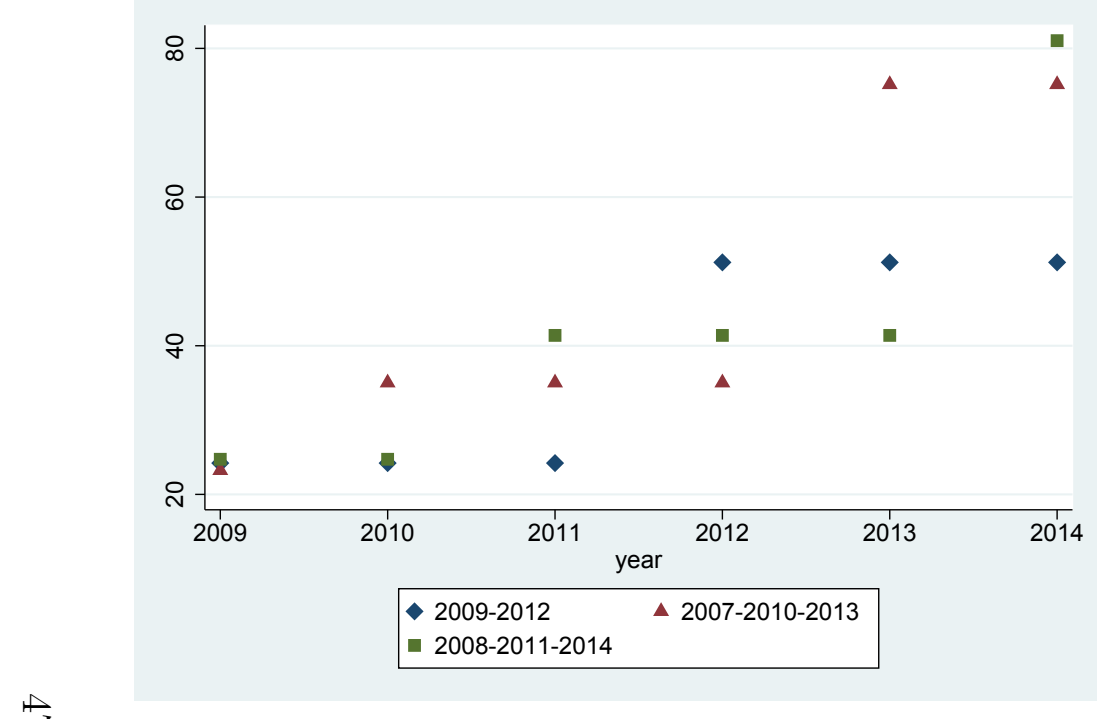

(a) Percentage of women with at least a degree

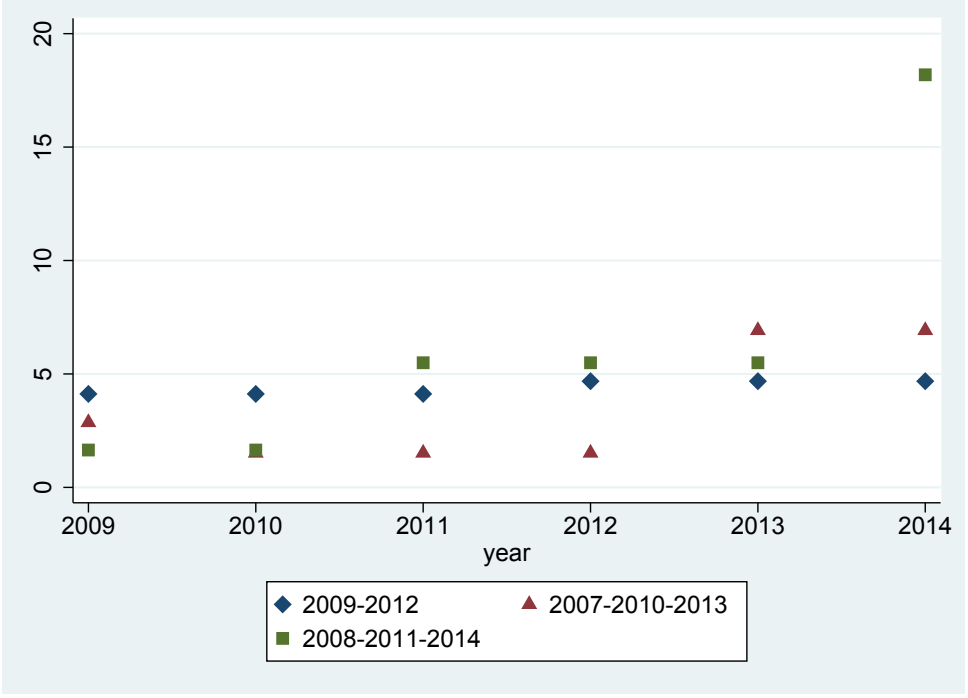

(b) Percentage of women with a graduate degree

Figure 3: Effect on women's education

Notes: Figures $3 \mathrm{a}$ and $3 \mathrm{~b}$ show respectively the evolution of the percentage of women with a university degree over time and the evolution of the percentage of women with a graduate degree (PhD, Master's program, MBA) over time. The cohorts 2009-2012, 2007-2010-2013, and 2008-2011-2014 are represented by different markers. The diamond represents the 2009-2012 cohort, the triangle is the 2007-2010-2013 cohort and the square corresponds to the 2008-2011-2014 cohort. 


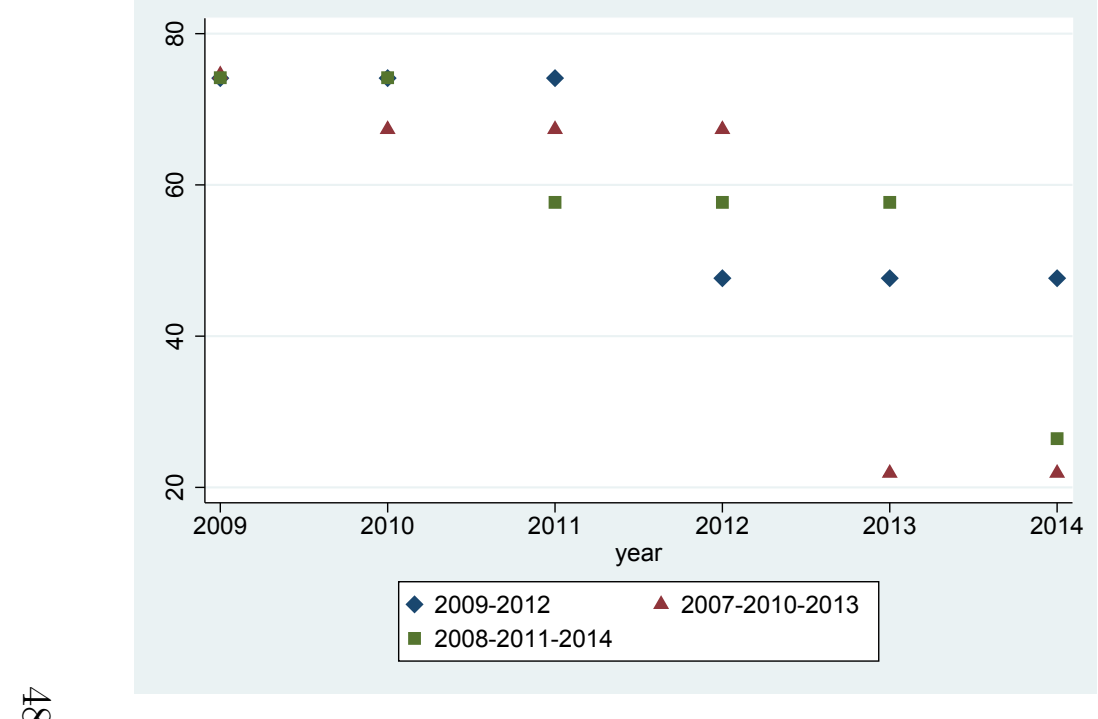

(a) Percentage of women older than 60

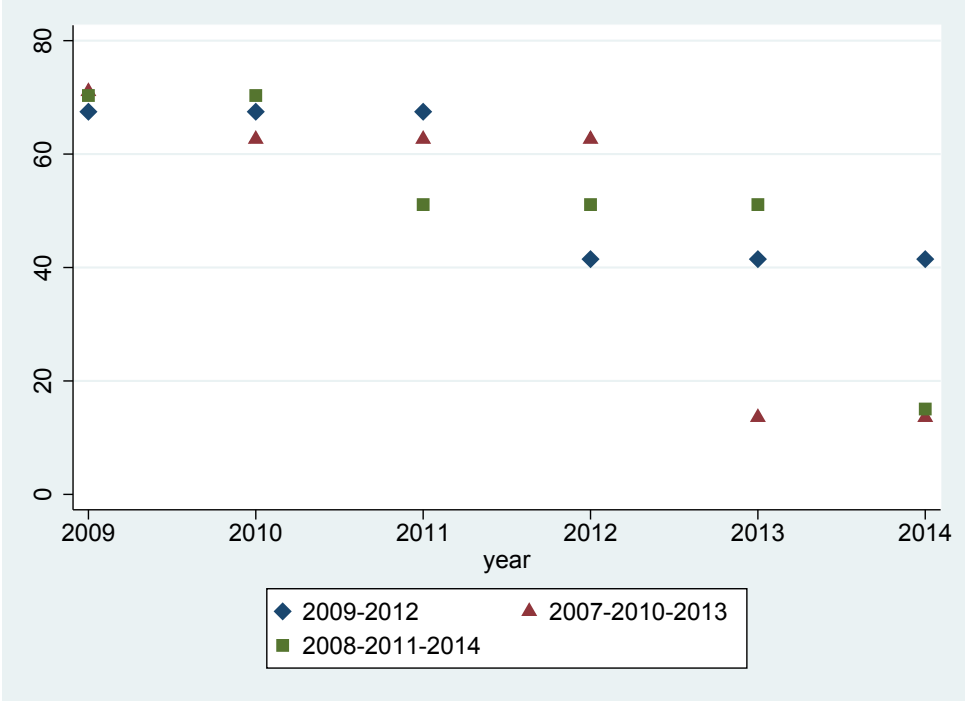

(b) Percentage of women older than 70

Figure 4: Effect on women's age

Notes: Figures $4 \mathrm{a}$ and $4 \mathrm{~b}$ show respectively the evolution of the percentage of women older than 60 and older than 70 over time. The cohorts 2009-2012, 2007-2010-2013, and 2008-2011-2014 are represented by different markers. The diamond represents the 2009-2012 cohort, the triangle is the 2007-2010-2013 cohort, and the square corresponds to the 2008-2011-2014 cohort. 
Table 5: IV regression: first stage

\begin{tabular}{lc}
\hline & $\%$ women directors \\
\hline \hline Reform & $(1)$ \\
& $0.1392^{* * *}$ \\
Year dummies & $(0.0076)$ \\
Firm fixed-effects & Yes \\
F-statistic & Yes \\
Observations & 147.55 \\
\hline
\end{tabular}

Notes: Results of the first stage regression of the percentage of women directors on the reform. Reform is an indicator variable that takes on value 1 over the reform period, and 0 otherwise. Standard errors are reported in parenthesis. ${ }^{*}$ Significant at $10 \%$; ${ }^{* *} 5 \%$; ** $1 \%$. 
Table 6: IV regression: effect on performance

\begin{tabular}{|c|c|c|c|c|c|c|c|}
\hline & $\begin{array}{c}\log (\text { empl }) \\
(1)\end{array}$ & $\begin{array}{c}\log (\text { prod }) \\
(2)\end{array}$ & $\begin{array}{c}\log \text { (profits) } \\
(3)\end{array}$ & $\begin{array}{c}\log (\text { assets }) \\
(4)\end{array}$ & $\begin{array}{l}\text { ROA } \\
(5)\end{array}$ & $\begin{array}{c}\text { Tobin's Q } \\
(7)\end{array}$ & $\begin{array}{c}\text { Short-term } \\
\text { debt } \\
(8)\end{array}$ \\
\hline$\%$ women directors & $\begin{array}{l}-0.105 \\
(0.303)\end{array}$ & $\begin{array}{c}0.069 \\
(0.726)\end{array}$ & $\begin{array}{l}-0.415 \\
(1.176)\end{array}$ & $\begin{array}{c}0.082 \\
(0.209)\end{array}$ & $\begin{array}{c}6.036 \\
(8.005)\end{array}$ & $\begin{array}{l}-1,510 \\
(0.994)\end{array}$ & $\begin{array}{l}-0.129 \\
(0.146)\end{array}$ \\
\hline Firm fixed-effects & Yes & Yes & Yes & Yes & Yes & Yes & Yes \\
\hline Year fixed-effects & Yes & Yes & Yes & Yes & Yes & Yes & Yes \\
\hline F-statistic & 2.54 & 0.50 & 1.10 & 0.29 & 3.88 & 1.27 & 4.89 \\
\hline Observations & 954 & 829 & 625 & 973 & 994 & 986 & 828 \\
\hline
\end{tabular}

Notes: Results of the IV regression of firms' performance measures on the share of female directors. Data are yearly observations from 2010 to 2014 . * Significant at $10 \% ; * * 5 \% ; * * * 1 \%$. 
Table 7: IV regression: effect on riskiness of stock prices

\begin{tabular}{lc}
\hline \hline Dependent variable: monthly standard deviation in the stock price & \\
\hline & Full sample \\
& $(1)$ \\
\hline Share of women directors & $-0.0092^{* * *}$ \\
& $(0.0031)$ \\
Constant & $0.0204^{* * *}$ \\
& $(0.0008)$ \\
Firm fixed effects & Yes \\
Month fixed effects & Yes \\
F-statistic & 31.31 \\
Observations & 7,644 \\
\hline Notes: Results of the IV regression of the monthly standard deviation of stock prices on the share of female
\end{tabular}
directors over the period $2011-2014$. ${ }^{*}$ Significant at $10 \% * * * 5 \% ; * * * 1 \%$. 
Table 8: Cumulative abnormal returns of Italian companies by gender diversity

\begin{tabular}{|c|c|c|c|c|}
\hline & $\begin{array}{l}\text { All firms } \\
(1) \\
\end{array}$ & $\begin{array}{c}\text { Above median } \\
\text { share of women } \\
(2)\end{array}$ & $\begin{array}{c}\text { Below median } \\
\text { share of women } \\
(3)\end{array}$ & $\begin{array}{c}\text { Difference } \\
(2)-(3) \\
(4) \\
\end{array}$ \\
\hline \multicolumn{5}{|c|}{ Panel A. Cumulative abnormal returns of Italian firms, 28 June 2011} \\
\hline Mean & $\begin{array}{c}-0.0128^{* * *} \\
(0.0036)\end{array}$ & $\begin{array}{c}-0.0127^{* * *} \\
(0.0051)\end{array}$ & $\begin{array}{c}-0.0129 * * * \\
(0.00525)\end{array}$ & $\begin{array}{l}-0.0002 \\
(0.0073)\end{array}$ \\
\hline Observations & 224 & 124 & 100 & 224 \\
\hline \multicolumn{5}{|c|}{ Panel B. Cumulative abnormal returns of Italian firms, 15 March 2011} \\
\hline Mean & $\begin{array}{c}0.0030 \\
(0.0038)\end{array}$ & $\begin{array}{c}0.0008 \\
(0.0049)\end{array}$ & $\begin{array}{l}0.0056 \\
(0.006)\end{array}$ & $\begin{array}{c}0.0047 \\
(0.0077)\end{array}$ \\
\hline Observations & 222 & 121 & 101 & 222 \\
\hline
\end{tabular}

Notes: t-tests of the mean cumulative abnormal returns (CARs) in columns 1-3 and test of the difference in means in column 4 . CARs are the sum of abnormal returns over the six days surrounding the announcement date $((-3 ;+3)$ event window). Column 1 reports the mean CAR of all Italian firms listed on the Italian stock exchange; columns 2 and 3 report the mean CAR of Italian firms whose share of women on the board of directors is respectively above and below the median value. Column 4 shows the test of the difference in means between the values in columns 2 and 3 . * Significant at $10 \% ; * * 5 \%$;** $1 \%$. 
Table 9: Effect of the announcement of the quota law on cumulative abnormal returns

Dependent variable: cumulative abnormal returns around the event date

June 28, 2011

(1)

Italian

$\%$ women directors

$\%$ women directors $*$ Italian

Above median share of women directors

ej Above median share of women directors * Italian

Board size

$\log ($ assets $)$

Constant

Industrial sectors

R-squared

Observations
$-0.0203^{*}$

$(0.008)$

$-0.0357$

(0.0438)

0.0605

(0.0564)

$\begin{array}{cc} & 0.0038 \\ & (0.0089) \\ & -0.0001 \\ & (0.0118) \\ 0.0018 & 0.00183 \\ (0.0011) & (0.00116) \\ -0.0001 & -0.0004 \\ (0.0018) & (0.0019) \\ -0.004 & -0.0054 \\ (0.0233) & (0.0232) \\ \text { Yes } & \text { Yes } \\ 0.1120 & 0.1107 \\ 283 & 283\end{array}$

283

$-0.0149^{* *}$
$(0.00797)$

$(0.00797)$

0.0038
$(2)$

***

(3)

0.0047

$(0.0123)$

$-0.0799$

(0.0711)

0.0811

(0.0903)

$-0.013$

$(0.0115)$

0.01477

$(0.0153)$

0.0001

$(0.0012)$

$-0.0016$

$(0.00115)$

$-0.0016$

$(0.0025)$

0.0424

(0.0367)

Yes

0.1136

(0.00248)

0.0424

(0.0366)

Yes

0.1129

282

282

Notes: Results of the event study on June 28, 2011 and March 15, 2011. Regressions are cross-section OLS regression on cumulative abnormal returns of Italian and Spanish firms. Cumulative abnormal returns are the sum of abnormal returns over the six days surrounding the announcement $((-3 ;+3)$ event window). Italian is a dummy variable indicating whether the firm is Italian; \% women directors records the percentage of women on board at the date of announcement. Above median share of women directors is a dummy indicating whether the share of women on board was above the median at the announcement date. Board size is the number of board members. Standard errors are clustered at the firm level. ${ }^{*}$ Significant at $10 \%$; ** $5 \%$; ** $1 \%$. 
Table 10: Effect of the quota law on cumulative abnormal returns

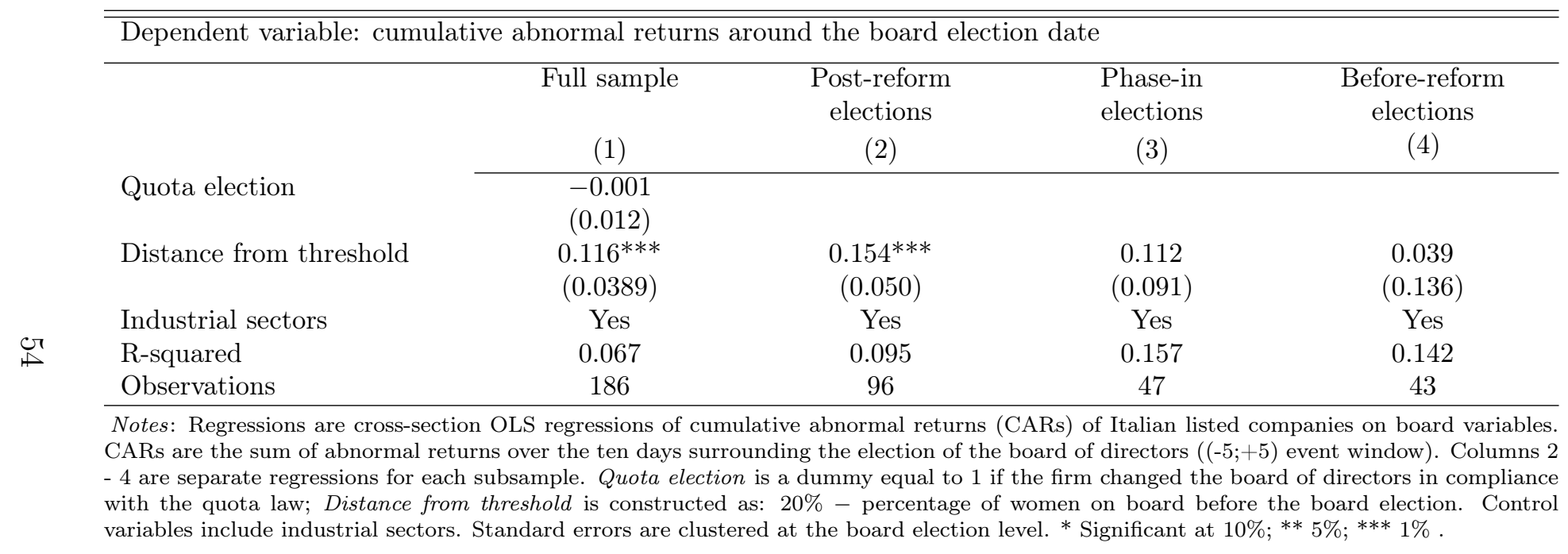


Table 11: Status quo before the reform. Italy and Norway.

\begin{tabular}{|c|c|c|c|c|c|c|c|}
\hline & & \multicolumn{3}{|c|}{ Italy } & \multicolumn{3}{|c|}{ Norway } \\
\hline & & 2009 & 2010 & 2011 & 2001 & 2002 & 2003 \\
\hline \multicolumn{8}{|l|}{ Panel A. Board-level variables } \\
\hline Number of members & & 10.27 & 10.01 & 9.93 & 5.54 & 5.53 & 5.39 \\
\hline Share of women $(\%)$ & & 6.54 & 7.42 & 9.12 & 5.42 & 7.47 & 10.97 \\
\hline Higher education (\%) & & & & & 25.38 & 26.15 & 28.14 \\
\hline Graduate degree (\%) & & 7.91 & 7.75 & 7.65 & & & \\
\hline Age & & 54.67 & 54.89 & 54.74 & 50.47 & 51.25 & 51.47 \\
\hline Retained from previous year & & & 49.50 & 47.08 & & 78.22 & 80.23 \\
\hline Number of positions & & 1.41 & 1.33 & 1.27 & 1.94 & 2.03 & 2.13 \\
\hline Observations & & 199 & 218 & 226 & 127 & 119 & 113 \\
\hline \multicolumn{8}{|l|}{ Panel B. Individual variables } \\
\hline \multirow[t]{2}{*}{ Age } & Women & 49.87 & 49.82 & 49.10 & 46.46 & 47.88 & 47.55 \\
\hline & Men & 55.44 & 55.82 & 55.83 & 50.51 & 51.18 & 52.34 \\
\hline Higher education (\%) & Women & & & & 25.00 & 26.67 & 34.15 \\
\hline \multirow[t]{2}{*}{ Graduate degree $(\%)$} & Women & 12.69 & 9.88 & 11.22 & & & \\
\hline & Men & 7.70 & 7.77 & 7.55 & & & \\
\hline \multirow[t]{2}{*}{ Number of positions } & Women & 1.41 & 1.30 & 1.19 & 1.08 & 1.22 & 1.22 \\
\hline & Men & 1.48 & 1.41 & 1.34 & 1.18 & 1.18 & 1.21 \\
\hline \multirow[t]{2}{*}{ Observations } & Women & 134 & 162 & 205 & 50 & 55 & 69 \\
\hline & Men & 1914 & 2020 & 2042 & 653 & 591 & 541 \\
\hline
\end{tabular}

Notes: Data are averages of average boards' of director characteristics (Panel A) and averages of directors' characteristics (Panel B) over the three years preceding the introduction of the quota law, for Italy and Norway. Data for Norway are from Ahern and Dittmar (2012).

Data on education are not strictly comparable. In Ahern and Dittmar (2012), higher education refers to board members with a postbaccalaureate degree, including MA, MS, MD, JD, and PhD. In our analysis, graduate degree refers to members with a Master's program, PhD, and MBA.

*Retained members for Italy are computed as follows. Retained members in 2010 refer to firms that changed their board in 2010. Retained members are those re-appointed from 2007. Retained members in 2011 refer to firms that changed their board in 2011. Retained members are those re-appointed from 2008. 


\section{References}

[1] Adams, R. and Ferreira D. (2009) Women in the boardroom and their impact on governance and performance. Journal of Financial Economics, 94:291309 .

[2] Adams, R. and Funk, P. (2012) Beyond the Glass Ceiling: Does Gender Matter? Management Science 58(2): 219-235.

[3] Adams, R., Gray, S. and Nowland, J. (2012) Does Gender Matter in the Boardroom? Evidence from the Market Reaction to Mandatory New Director Announcements, available at SSRN.

[4] Adams, R. B. and Ferreira, D. (2003) Diversity and incentives in teams: Evidence from corporate boards. Working Paper, University of Stockholm.

[5] Adams, R. and Ragunathan (2013) Lehman Sisters, FIRN research paper.

[6] Ahern K. R. and Dittmar A. K. (2012) The changing of the boards: the impact on firm valuation of female board representation. The Quarterly Journal of Economics, 127:137- 197.

[7] Amore, M. D., Garofalo, O., and Minichilli, A. (2014) Gender interactions within the family firm. Management Science: 1083-1097.

[8] Bagues, M. and Esteve-Volart, B. (2010) Can gender parity break the glass ceiling? Evidence from a repeated randomized experiment. Review of Economic Studies 77: 1301-1328.

[9] Baltrunaite, A., Bello, P., Casarico, A. and Profeta, P. (2014) Gender quotas and the quality of politicians. Journal of Public Economics 118:62-74.

[10] Baltrunaite, A., Casarico, A. and Profeta, P. (2015) Affirmative action and the power of the elderly. CESifo Economic Studies 61(1): 148-164.

[11] Beaman, L., Chattopadhyay, R., Duflo, E., Pande, R., and Topalova, P. (2009) Powerful Women: Does Exposure Reduce Bias?. Quarterly Journal of Economics 124 (4): 1497-1540.

[12] Bertrand, M. (2011) New Perspectives on Gender, in Card D. and Ashenfelter O. (eds.) Handbook of Labor Economics, Vol. 4b, Chapter 17.

[13] Bertrand M., Black S. E., Jensen S. and Lleras-Muney A. (2014), Breaking the glass ceiling? The effect of board quotas on female labor market outcomes in Norway. NBER Working Paper No. 20256.

[14] Besley, T. J., Folke, O., Persson, T. and Rickne, J., (2013) Gender Quotas and the Crisis of the Mediocre Man: Theory and Evidence from Sweden (November 7, 2013). IFN Working Paper No. 985. 
[15] Bianco, M., Ciavarella, A., Signoretti, R. (2015) Women on corporate boards in Italy: the role of family connections, Corporate Governance, An International Review, Vol. 23, Issue 2, pp. 129-144.

[16] Bohern, O. and Staubo, S. (2014) Does mandatory gender balance work? Changing organizational firm to avoid board upheaval. Journal of Corporate Finance 28: 152-168.

[17] Chapple, L. and Humphrey, J. E. (2014) Does board gender diversity have a financial impact? Evidence using stock portfolio performance. Journal of Business Ethics, 122:709Đ723.

[18] Chattopadhyay, R., and Duflo E. (2004) Women as Policy Makers: Evidence from Randomized Policy Experiment in India. Econometrica, 72(5): 1409-43.

[19] Conde-Ruiz, J. I. and Hoya, C. (2015) Gender (in)equality act and large Spanish corporations. Fedea Policy Papers, 3.

[20] Consob (2015) Relazione annuale.

[21] Dhir, A. (2015) Challenging boardroom homogeneity. Cambridge University Press.

[22] Dobbin, F. and Jung, J. (2011) Corporate board gender diversity and stock performance: The competence gap or institutional investor bias. North Carolina Law Review, 89(3):809-840.

[23] Engelstad, F. and Teigen, M. (2012) Firms, Boards and Gender quotas: Comparative perspectives. Emerald, UK.

[24] Fernàndez, R. (2013) Cultural Change as Learning: The Evolution of Female Labor Force Participation over a Century, American Economic Review, 103 (1), pp. 472-50, 2013.

[25] Fernàndez, R., Fogli, A. and Olivetti, C. (2004) Mothers and Sons: Preference Formation and Female Labor Force Dynamics, Quarterly Journal of Economics, 119 (4), pp. 1249-1299.

[26] Flabbi, L., Macis, M., Moro, A. and Schivardi, F. (2014) Do female executives make a difference? The impact of female leadership on gender gaps and firm performance, MIMEO.

[27] Galasso, V. and Nannicini, T. (2011). Competing on Good Politicians, American Political Science Review, 105(1), 79-99.

[28] Gagliarducci, S. and Paserman, D. (2014) The Effect of Female Leadership on Establishment and Employee Outcomes: Evidence from Linked EmployerEmployee Data IZA DP 8647. 
[29] Holzer, H. J., and Neumark, D. (2006) Affirmative action: What do we know?, The Journal of Policy Analysis and Management 26(2): 463-90.

[30] Hoogendoorn, S., Oosterbeek, H. and van Praag, M. (2013) The Impact of Gender Diversity on the Performance of Business Teams: Evidence from a Field Experiment, Management Science.

[31] Huse, M. and Seierstad, C. (2013) Getting women on to corporate boards: Consequences of the Norwegian gender balance law. The European Financial Review 12:37-39.

[32] IMF (2014) Annual Report 2014. From stabilization to sustainable growth, IMF, Washington D.C..

[33] Kothari, S. and Warner, J. B. (2004) Econometrics of event studies. Empirical Corporate Finance.

[34] Lee, P. M. and James, E. H. (2007) She-e-os: gender effects and investor reactions to the announcements of top executive appointments. Strategic Management Journal, 28(3):227Đ241.

[35] Matsa D. A. and Miller A. R. (2013), A female style in corporate leadership? Evidence from quotas. American Economic Journal: Applied Economics, 5(3):136-169.

[36] Nygaard, K. (2011). Forced board changes: Evidence from Norway. Institutt for Samfunnsokonomi, The Norwegian School of Economics and Business Administration.

[37] OECD (2012), Closing the Gender Gap, OECD Publishing, Paris.

[38] Profeta P., Amidani Alberti L., Casarico A., D’Amico M. and Puccio A., (2014) Women Directors - The Italian Way and Beyond. Palgrave Macmillan.

[39] Pande, R., and Ford, D. (2011) Gender Quotas and Female Leadership: A Review. Background Paper for the World Development Report on Gender.

[40] Ryan, M. K. and Haslam, S. A. (2005) The glass cliff: Evidence that women are over-represented in precarious leadership positions. British Journal of Management, 16:81-90.

[41] Rose, C. (2007) Does female board representation influence firm performance? The Danish evidence, Corporate Governance. An International Review 2: 404-13.

[42] Rossi, F. and Cebula, R. (2015) Stock market reactions to announcements of the board of directors: Evidence from Italy, Applied Economics. 
[43] Seierstad, C. and Opsahl, T. (2011). For the few not the many? The effects of affirmative action on presence, prominence, and social capital of women directors in Norway. Scandinavian Journal of Management 27 (1).

[44] Schwartz-Ziv, M. (2015). Gender and Board Activeness: The Role of a Critical Mass. Journal of Financial and Quantitative Analysis, Forthcoming.

[45] Terjesen, S., Aguilera, R.V. and Lorenz, R. (2013) Legislating a womanÕs seat on the board: Institutional factors driving gender quotas for boards of directors. Journal of Business Ethics.

[46] Van Der Walt, N., and Ingley, C. (2003) Board Dynamics and the Influence of Professional Background, Gender and Ethnic Diversity of Directors. Corporate Governance 11 (3): 218-34.

[47] Wang M., Kelan E., (2013) The Gender Quota and Female Leadership: Effects of the Norwegian Gender Quota on Board Chairs and CEOs. Journal of Business Ethics 117:449-466.

[48] Wegge, J. and K. H. Schmidt (2009) The Impact of Age Diversity in Teams on Group Performance, Innovation and Healt, in A. S. G. Antoniou and E. Elgar, eds., Handbook of Managerial Behavior and Occupational Health, Edward Elgar Publishing, UK, pp. 79-94.

[49] Wiersema, M. F. and K. A. Bantel (1992) Top Management Team Demography and Corporate Strategic Change, Academy of Management Journal 35, 91-121.

[50] Wolfers, J. (2010) Diagnosing discrimination: Stock returns and CEO gender. Journal of the European Economic Association, 4(2-3):531-541.

[51] World Economic Forum (2015) The Global Gender Gap Report 2015, World Economic Forum, Geneva. 


\section{APPENDIX}

\section{A.1 Board characteristics}

We introduce an alternative identification strategy to assess the impact of the gender quota law on board characteristics. For 2013, we present average values of board members' characteristics in the three groups of companies (pre-reform, phase-in and reform), which are exogenously selected. Results in Table A2 show that the share of women significantly increases in the reform sample (even more than the $20 \%$ initial target). ${ }^{33}$ The reform increases the share of members with graduate-level education, driven by men; it decreases the share of members older than 70; and it does not change the average number of board positions held by either men or women; it increases the percentage of family ties within the board, especially in the phase-in period. Our results also suggest an increase in the share of women with a degree in economics and an increase in field diversity.

\section{A.2 Announcement of the quota law}

We propose an alternative method of assessing the reaction of the financial market to the announcement of the introduction of the female quota law. We exploit the fact that board renewals of Italian companies are staggered to study whether stock market returns differ significantly between companies that will change their board under the new rule in 2013 relative to companies that have more time to adapt to the new policy. The idea is that firms that will be affected by the law first may experience significantly different stock returns at the announcement of the law compared to firms that have more time to adapt to the policy. In fact, if firms judge the reform as a costly constraint, then the timing of implementation of the law should matter. We compare stock market returns of companies in three random groups: pre-reform, phase-in and post-reform. Pre-reform firms changed their board in 2011; phase-in firms had elections in 2012, and post-reform firms changed their board in 2013, when the quota law became mandatory.

We perform the following cross-section OLS regression:

$$
C A R_{i, t}=\alpha+\beta \text { Election in } 2013_{i}+\phi \chi_{i}+\epsilon_{i}
$$

where Election in $2013_{i}$ is an indicator variable indicating whether the firm changed the board in 2013, namely in the year when the quota law became binding for firms; $\chi_{i}$ is a vector of control variables including board size, the logarithm

\footnotetext{
${ }^{33}$ As the law aims to reach the closer, higher rounded number, we have added a unit to the non-entire number.
} 
of assets, and industrial sector dummies. $\epsilon_{i}$ represents the error term. Standard errors are clustered at the firm level.

In Table A3 we compare stock price performance for the three subgroups. The results in Table A2 show that mean CARs are negative and significant for each group, confirming that there is no difference in stock price performance among Italian firms that changed their boards in 2013 — thus being first affected by the law - and other firms. Moreover, we check whether there are statistically significant differences in the mean CARs between each of the three groups and the others, and find no significant differences between groups.

Table A4 shows the results of Equation 10, where we perform a simple crosssection OLS regression to provide additional evidence of the absence of a differential effect of the law on the three subgroups. We find that, as expected, the law does not have any significant effect on the CASs of firms that were first affected by the law relative to other firms, neither on June 28, 2011, nor on March 15, 2011. The announcement of the law might have had ambiguous effects on the phase-in group, as these firms changed their boards in 2012, after the approval of the law but before its actual enforcement. To address this concern, in columns 2 and 4 of Table A4, we drop the "phase-in" group from the sample, and find analogous results. 
Table A1 Summary statistics: board characteristics (individual level)

\begin{tabular}{|c|c|c|c|c|c|c|c|}
\hline & & 2009 & 2010 & 2011 & 2012 & 2013 & 2014 \\
\hline \multicolumn{8}{|l|}{ Panel A. Directors } \\
\hline \multirow[t]{3}{*}{ Number of members } & All & 11.55 & 11.33 & 11.31 & 11.11 & 11.18 & 11.06 \\
\hline & Women & 0.73 & 0.82 & 1.01 & 1.36 & 1.99 & 2.32 \\
\hline & Men & 10.81 & 10.50 & 10.30 & 9.75 & 9.19 & 8.75 \\
\hline \multicolumn{8}{|l|}{ Education } \\
\hline \multirow[t]{3}{*}{$\%$ university degree } & All & 84.21 & 84.01 & 85.05 & 86.23 & 87.76 & 87.69 \\
\hline & Women & 70.00 & 74.83 & 82.90 & 87.64 & 89.54 & 89.53 \\
\hline & Men & 85.23 & 84.75 & 85.27 & 86.02 & 87.37 & 87.18 \\
\hline \multirow[t]{3}{*}{$\%$ graduate degree } & All & 8.02 & 7.93 & 7.88 & 7.45 & 8.04 & 9.99 \\
\hline & Women & 12.69 & 9.88 & 11.22 & 10.11 & 14.56 & 18.74 \\
\hline & Men & 7.70 & 7.77 & 7.55 & 7.08 & 6.63 & 7.65 \\
\hline Field diversity & All & 0.45 & 0.45 & 0.45 & 0.46 & 0.45 & 0.44 \\
\hline \multirow[t]{3}{*}{$\%$ study abroad } & All & 8.40 & 7.67 & 7.74 & 9.01 & 6.00 & 8.39 \\
\hline & Women & 6.06 & 7.87 & 9.02 & 12.70 & 8.59 & 12.71 \\
\hline & Men & 8.54 & 7.65 & 7.61 & 8.44 & 5.44 & 7.17 \\
\hline \multirow[t]{3}{*}{$\%$ degree in economics } & All & 37.38 & 38.18 & 40.12 & 41.63 & 41.83 & 41.32 \\
\hline & Women & 31.34 & 33.95 & 39.51 & 41.88 & 39.62 & 41.68 \\
\hline & Men & 37.80 & 38.51 & 40.18 & 41.59 & 42.31 & 41.23 \\
\hline \multirow[t]{3}{*}{$\%$ degree in law } & All & 13.50 & 13.89 & 13.62 & 13.29 & 14.64 & 15.40 \\
\hline & Women & 8.21 & 9.26 & 10.73 & 14.44 & 18.38 & 20.00 \\
\hline & Men & 13.87 & 14.26 & 13.91 & 13.13 & 13.83 & 14.17 \\
\hline \multirow[t]{3}{*}{$\%$ degree in political science } & All & 2.94 & 3.25 & 3.65 & 3.46 & 3.62 & 3.60 \\
\hline & Women & 3.73 & 3.70 & 5.85 & 4.33 & 5.49 & 4.84 \\
\hline & Men & 2.88 & 3.22 & 3.43 & 3.33 & 3.21 & 3.26 \\
\hline \multirow[t]{3}{*}{$\%$ degree in engineering } & All & 11.99 & 12.33 & 12.56 & 11.94 & 11.96 & 11.54 \\
\hline & Women & 4.48 & 4.94 & 6.83 & 6.50 & 5.73 & 4.63 \\
\hline & Men & 12.51 & 12.92 & 13.13 & 12.72 & 13.31 & 13.39 \\
\hline \multicolumn{8}{|l|}{ Age } \\
\hline \multirow[t]{3}{*}{$\%$ older than 60} & All & 38.25 & 39.29 & 38.01 & 42.71 & 41.78 & 40.27 \\
\hline & Women & 21.14 & 20.39 & 17.09 & 18.45 & 17.63 & 17.53 \\
\hline & Men & 39.45 & 40.82 & 40.17 & 46.17 & 47.00 & 46.19 \\
\hline \multirow[t]{3}{*}{$\%$ older than 70} & All & 12.06 & 12.28 & 12.31 & 16.62 & 16.65 & 15.26 \\
\hline & Women & 4.07 & 3.95 & 3.02 & 4.80 & 5.07 & 4.49 \\
\hline & Men & 12.62 & 12.85 & 13.23 & 18.31 & 19.14 & 19.11 \\
\hline \multicolumn{8}{|l|}{ Family ties } \\
\hline \multirow[t]{2}{*}{$\%$ family members } & All & 8.33 & 7.99 & 7.80 & 11.41 & 10.89 & 11.15 \\
\hline & Women & 22.39 & 19.75 & 14.63 & 17.33 & 12.65 & 12.03 \\
\hline
\end{tabular}


Table A1 Summary statistics: board characteristics (individual level)

\begin{tabular}{|c|c|c|c|c|c|c|c|}
\hline & & 2009 & 2010 & 2011 & 2012 & 2013 & 2014 \\
\hline & Men & 7.34 & 7.04 & 7.11 & 10.57 & 10.51 & 10.92 \\
\hline \multicolumn{8}{|l|}{ Multiple positions } \\
\hline \multirow{3}{*}{ Average number of positions } & & 1.46 & 1.38 & 1.30 & 1.33 & 1.36 & 1.34 \\
\hline & Women & 1.52 & 1.36 & 1.20 & 1.20 & 1.27 & 1.27 \\
\hline & Men & 1.46 & 1.38 & 1.31 & 1.35 & 1.39 & 1.36 \\
\hline \multicolumn{8}{|l|}{ Retained members } \\
\hline \multirow[t]{3}{*}{$\%$ retained } & All & & & & 50.29 & 50.13 & 54.13 \\
\hline & Women & & & & 29.60 & 25.54 & 28.57 \\
\hline & Men & & & & 53.23 & 55.46 & 60.87 \\
\hline Observations & & 2,044 & 2,182 & 2,246 & 2,227 & 2,350 & 2,253 \\
\hline \multicolumn{8}{|l|}{ Panel B. Statutory auditors } \\
\hline \multirow[t]{3}{*}{ Number of members } & All & 11.55 & 11.33 & 11.31 & 11.11 & 11.18 & 11.06 \\
\hline & Women & 0.73 & 0.82 & 1.01 & 1.36 & 1.99 & 2.32 \\
\hline & Men & 10.81 & 10.50 & 10.30 & 9.75 & 9.19 & 8.75 \\
\hline \multicolumn{8}{|l|}{ Education } \\
\hline \multirow[t]{3}{*}{$\%$ university degree } & All & 84.21 & 84.01 & 85.05 & 86.23 & 87.76 & 87.69 \\
\hline & Women & 70.00 & 74.83 & 82.90 & 87.64 & 89.54 & 89.53 \\
\hline & Men & 85.23 & 84.75 & 85.27 & 86.02 & 87.37 & 87.18 \\
\hline \multirow[t]{3}{*}{$\%$ graduate degree } & All & 8.02 & 7.93 & 7.88 & 7.45 & 8.04 & 9.99 \\
\hline & Women & 12.69 & 9.88 & 11.22 & 10.11 & 14.56 & 18.74 \\
\hline & Men & 7.70 & 7.77 & 7.55 & 7.08 & 6.63 & 7.65 \\
\hline Field diversity & All & 0.45 & 0.45 & 0.45 & 0.46 & 0.45 & 0.44 \\
\hline \multirow[t]{3}{*}{$\%$ study abroad } & All & 8.40 & 7.67 & 7.74 & 9.01 & 6.00 & 8.39 \\
\hline & Women & 6.06 & 7.87 & 9.02 & 12.70 & 8.59 & 12.71 \\
\hline & Men & 8.54 & 7.65 & 7.61 & 8.44 & 5.44 & 7.17 \\
\hline \multirow[t]{3}{*}{$\%$ degree in economics } & All & 37.38 & 38.18 & 40.12 & 41.63 & 41.83 & 41.32 \\
\hline & Women & 31.34 & 33.95 & 39.51 & 41.88 & 39.62 & 41.68 \\
\hline & Men & 37.80 & 38.51 & 40.18 & 41.59 & 42.31 & 41.23 \\
\hline \multirow[t]{3}{*}{$\%$ degree in law } & All & 13.50 & 13.89 & 13.62 & 13.29 & 14.64 & 15.40 \\
\hline & Women & 8.21 & 9.26 & 10.73 & 14.44 & 18.38 & 20.00 \\
\hline & Men & 13.87 & 14.26 & 13.91 & 13.13 & 13.83 & 14.17 \\
\hline \multirow[t]{3}{*}{$\%$ degree in political science } & All & 2.94 & 3.25 & 3.65 & 3.46 & 3.62 & 3.60 \\
\hline & Women & 3.73 & 3.70 & 5.85 & 4.33 & 5.49 & 4.84 \\
\hline & Men & 2.88 & 3.22 & 3.43 & 3.33 & 3.21 & 3.26 \\
\hline \multirow[t]{3}{*}{$\%$ degree in engineering } & All & 11.99 & 12.33 & 12.56 & 11.94 & 11.96 & 11.54 \\
\hline & Women & 4.48 & 4.94 & 6.83 & 6.50 & 5.73 & 4.63 \\
\hline & Men & 12.51 & 12.92 & 13.13 & 12.72 & 13.31 & 13.39 \\
\hline
\end{tabular}


Table A1 Summary statistics: board characteristics (individual level)

\begin{tabular}{lrcccccc}
\hline & & 2009 & 2010 & 2011 & 2012 & 2013 & 2014 \\
\hline \hline Age & & & & & & & \\
\hline \% older than 60 & All & 38.25 & 39.29 & 38.01 & 42.71 & 41.78 & 40.27 \\
& Women & 31.14 & 20.39 & 17.09 & 18.45 & 17.63 & 17.53 \\
\% older than 70 & All & 39.45 & 40.82 & 40.17 & 46.17 & 47.00 & 46.29 \\
& Women & 4.07 & 3.95 & 3.02 & 4.80 & 5.07 & 4.49 \\
& Men & 12.62 & 22.85 & 13.17 & 18.31 & 19.14 & 18.11 \\
\hline Family ties & & & & & & & \\
\hline \% family members & All & 8.33 & 7.99 & 7.80 & 11.41 & 10.89 & 11.15 \\
& Women & 22.39 & 19.75 & 14.63 & 17.33 & 12.65 & 12.03 \\
& Men & 7.34 & 7.04 & 7.11 & 10.57 & 10.51 & 10.92 \\
\hline Multiple positions & & & & & & & \\
\hline Average number of positions & & 1.47 & 1.38 & 1.24 & 1.22 & 1.27 & 1.23 \\
& Women & 1.14 & 1.11 & 1.04 & 1.09 & 1.18 & 1.15 \\
& Men & 1.49 & 1.40 & 1.26 & 1.24 & 1.30 & 1.25 \\
\hline Retained members & & & & & & & \\
\hline \% retained & All & & & & 50.29 & 50.13 & 54.13 \\
& Women & & & & 29.60 & 25.54 & 28.57 \\
& Men & & & & 53.23 & 55.46 & 60.87 \\
\hline Observations & 2,044 & 2,182 & 2,246 & 2,227 & 2,350 & 2,253 \\
\hline
\end{tabular}

Notes: Average board characteristics of Italian listed companies over the period 2009-2014, separately for board of directors (Panel A) and board of statutory auditors (Panel B). 
Table A2 Effect on board characteristics

\begin{tabular}{|c|c|c|c|c|}
\hline & & $\begin{array}{c}\text { Pre-reform } \\
\text { (1) }\end{array}$ & $\begin{array}{c}\text { Phase-in } \\
\text { (2) }\end{array}$ & $\begin{array}{c}\text { Post-reform } \\
\text { (3) }\end{array}$ \\
\hline \multicolumn{5}{|l|}{ Women's empowerment } \\
\hline Share of women & & 10.5 & $14.6^{* * *}$ & $28.6^{* * *}$ \\
\hline More than $20 \%$ of women & & 3.3 & 4.0 & $17.1^{* * *}$ \\
\hline Female president & & 4.9 & 6.0 & 7.0 \\
\hline Female CEO & & 1.7 & 9.1 & 3.6 \\
\hline \multicolumn{5}{|l|}{ Education } \\
\hline \multirow[t]{3}{*}{$\%$ university degree } & All & 82.8 & 84.0 & 85.7 \\
\hline & Women & 77.4 & 84.6 & 85.6 \\
\hline & Men & 83.2 & 83.3 & 85.5 \\
\hline \multirow[t]{3}{*}{$\%$ graduate degree } & All & 3.9 & 4.7 & $7.4^{* * *}$ \\
\hline & Women & 9.5 & 6.8 & 9.6 \\
\hline & Men & 3.5 & 4.6 & $6.9^{* * *}$ \\
\hline \multirow[t]{3}{*}{$\%$ study abroad } & All & 2.6 & 3.4 & 2.4 \\
\hline & Women & 3.8 & 5.4 & 4.4 \\
\hline & Men & 2.6 & 3.1 & 1.7 \\
\hline \multirow[t]{3}{*}{$\%$ degree in economics } & All & 57.7 & 58.8 & 56.0 \\
\hline & Women & 42.1 & 51.0 & $54.0^{*}$ \\
\hline & Men & 58.7 & 58.7 & 55.9 \\
\hline \multirow{3}{*}{$\%$ degree in law } & All & 9.8 & 9.7 & 11.2 \\
\hline & Women & 9.7 & 13.2 & 13.0 \\
\hline & Men & 9.7 & 9.2 & 11.0 \\
\hline Field diversity & All & 0.7 & 0.6 & $0.6^{*}$ \\
\hline Age & & & & \\
\hline
\end{tabular}


Table A2 Effect on board characteristics

\begin{tabular}{lrccc}
\hline & & Pre-reform & Phase-in & Post-reform \\
& & $(1)$ & $(2)$ & $(3)$ \\
\hline \hline \% older than 60 & All & 39.8 & 36.3 & 35.6 \\
& Women & 18.4 & 17.0 & 12.3 \\
\% older than 70 & Men & 42.0 & 38.8 & 45.6 \\
& All & 21.4 & $15.6^{* *}$ & $12.0^{* * *}$ \\
& Women & 5.9 & 3.1 & 4.3 \\
\hline Family ties & Men & 23.0 & $17.2^{* *}$ & $15.2^{* * *}$ \\
\hline \% family ties within the board & All & 4.5 & $7.5^{* *}$ & \\
& Women & 12.7 & 14.1 & 5.1 \\
& Men & 4.2 & $6.9^{* *}$ & 6.5 \\
\hline Multiple positions & & & & \\
\hline Average number of positions & All & 1.3 & 1.3 & 1.3 \\
& Women & 0.8 & 0.8 & 0.8 \\
& Men & 0.8 & 0.8 & 0.8 \\
\hline
\end{tabular}

Notes: Averages of members' characteristics in 2013. Pre-reform firms changed their board in 2011; Phase-in firms had elections in 2012 and Post-reform firms changed their board in 2013 ${ }^{*}$ Significant at $10 \%$; ${ }^{* *} 5 \%$; ** $1 \%$. ${ }^{*}$ Significant at $10 \%$;* $5 \%$; ${ }^{* *} 1 \%$. 
Table A3 Cumulative abnormal returns of Italian companies by date of election

\begin{tabular}{|c|c|c|c|c|}
\hline & $\begin{array}{c}\text { Full sample } \\
(1)\end{array}$ & $\begin{array}{l}\text { Reform } \\
(2)\end{array}$ & $\begin{array}{c}\text { Phase-in } \\
(3)\end{array}$ & $\begin{array}{c}\text { Pre-reform } \\
(4)\end{array}$ \\
\hline \multicolumn{5}{|c|}{ Panel A. Cumulative abnormal returns of Italian firms, 28 June 2011} \\
\hline \multirow[t]{2}{*}{ Mean } & $-0.0128^{* * *}$ & $-0.0167^{* * *}$ & $-0.0127 * * *$ & $-0.0007^{* * *}$ \\
\hline & $(0.0036)$ & $(0.0066)$ & $(0.0047)$ & $(0.009)$ \\
\hline Observations & 224 & 75 & 83 & 51 \\
\hline \multicolumn{5}{|c|}{ Panel B. Cumulative abnormal returns of Italian firms, 15 March 2011} \\
\hline \multirow[t]{2}{*}{ Mean } & 0.003 & -0.0001 & 0.0011 & 0.0111 \\
\hline & $(0.0038)$ & $(0.0062)$ & $(0.0049)$ & $(0.0110)$ \\
\hline Observations & 222 & 74 & 83 & 51 \\
\hline
\end{tabular}

Notes: t-tests of the mean cumulative abnormal returns (CARs). CARs are the sum of abnormal returns over the six days surrounding the announcement $((-3 ;+3)$ event window). Column 1 reports the mean CAR of all Italian firms listed on the Italian stock exchange. Column 2 shows the mean value of the CAR of firms that would change their board in 2013, thus being the first affected by the reform. Column 2 reports the mean CAR for firms that would change their board in 2012, namely during the "phase-in" period; column 3 shows the mean CAR for firms that changed their board immediately before the approval of the law. ${ }^{*}$ Significant at $10 \% ; * * 5 \%$; ** $1 \%$. 
Table A4 Effect of the announcement of the quota law on cumulative abnormal returns

\begin{tabular}{lcccc}
\hline \multicolumn{2}{l}{ Dependent variable: cumulative abnormal returns around the event date } & \multicolumn{2}{c}{ March 15, 2011 } \\
\hline & \multicolumn{2}{c}{ June 28,2011} & $(3)$ & $(4)$ \\
\cline { 2 - 5 } Election in 2013 & $(1)$ & -0.0076 & -0.0009 & -0.0198 \\
& -0.0035 & $(0.0133)$ & $(0.0083)$ & $(0.0126)$ \\
Board size & $(0.0091)$ & 0.0018 & 0.0020 & 0.0045 \\
& 0.0016 & $(0.0021)$ & $(0.0012)$ & $(0.0021)$ \\
Log(assets) & $(0.0016)$ & 0.0014 & $-0.0053^{*}$ & -0.0081 \\
& 0.0005 & $(0.0045)$ & $(0.0031)$ & $(0.0051)$ \\
Industrial sectors & $(0.0030)$ & Yes & Yes & Yes \\
R-squared & Yes & 0.1934 & 0.15 & 0.2243 \\
Observations & 0.1313 & 105 & 177 & 105 \\
\hline
\end{tabular}

Notes: Results of the event study on June 28, 2011 and March 15, 2011. Regressions are cross-section OLS regression on cumulative abnormal returns of Italian firms. Cumulative abnormal returns are the sum of abnormal returns over the six days surrounding the announcement $((-3 ;+3)$ event window). Election in 2013 is a dummy variable indicating whether the firm would change the board in 2013. Board size is the number of board members. Standard errors are clustered at the firm level. ${ }^{*}$ Significant at $10 \%$; $* *$; $* * * 1 \%$. 
Table A5 Effect of board characteristics on cumulative abnormal returns before the quota law (2009-2011)

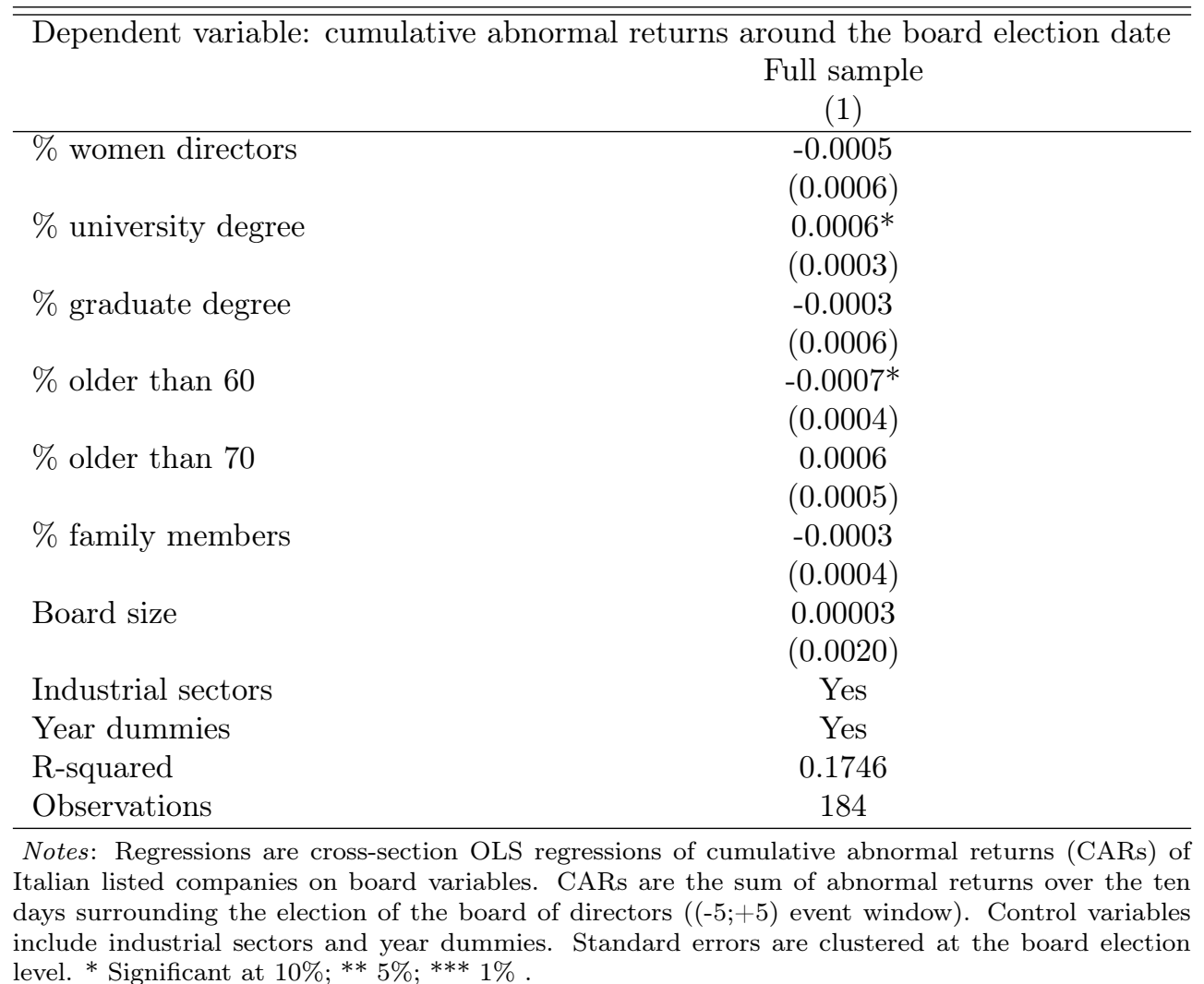

